\title{
Moisture Transport Associated with Southwest Monsoon Rainfall Over Sri Lanka in Relatively Wet and Dry Rainfall Years
}

Sherly Shelton ( $\square$ sherly@mail.iap.ac.cn )

Institute of Atmospheric Physics Chinese Academy of Sciences

\section{Research Article}

Keywords: Southwest monsoon, wet and dry monsoon years, moisture flux, moisture convergence, Arabian Sea

Posted Date: November 29th, 2021

DOl: https://doi.org/10.21203/rs.3.rs-894605/v1

License: (c) (1) This work is licensed under a Creative Commons Attribution 4.0 International License.

Read Full License 
relatively wet and dry rainfall years

Sherly Shelton ${ }^{1,2,4^{*}}$

$$
\text { Sherly Shelton }
$$

(1)

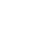

${ }^{1}$ International Center for Climate and Environment Sciences, Institute of Atmospheric Physics, Chinese Academy of Sciences, P.O. Box 9804, Beijing 100029, China

${ }^{2}$ College of Earth and Planetary Sciences (CEPS)' University of Chinese Academy of 8 Sciences, Beijing 100049, China

${ }^{3}$ Industrial Technology Institute, Colombo, Sri Lanka

\footnotetext{
Corresponding Author: Email: sherly@mail.iap.ac.cn
} 
Abstract: Atmospheric moisture transportation associated with the occurrence of relatively wet and dry southwest monsoon (SWM) years over Sri Lanka is still not fully understood. This study focused on investigating the role of moisture transport in contrast SWM years. We selected seven wet $\left(\mathrm{SWM}_{\mathrm{Wet}}\right)$ and nine dry $\left(\mathrm{SWM}_{\text {Dry }}\right)$ years for 1985-2015 and found that the whole country experiences above-average (below average) rainfall in $\mathrm{SWM}_{\mathrm{Wet}}\left(\mathrm{SWM}_{\text {Dry }}\right)$ years. In $\mathrm{SWM}_{\mathrm{Wet}}$ years, strengthening moisture-laden low-level jets (LLJ) from the Arabian Sea bring a large amount of moisture towards Sri Lanka. In contrast, the weakening of the LLJ from the Arabian Sea direction is observed in SWM Dry years. As a consequence, the climatological mean of net moisture flux $\left(4.35 \times 10^{5} \mathrm{~kg} \mathrm{~s}^{-1}\right)$ over the study domain is increased $\left(5.33 \times 10^{5} \mathrm{~kg} \mathrm{~s}^{-1}\right)$ and decreased $\left(3.98 \times 10^{5} \mathrm{~kg} \mathrm{~s}^{-1}\right)$ in $\mathrm{SWM}_{\mathrm{Wet}}$ and $\mathrm{SWM}_{\text {Dry }}$ years, respectively. With respect to long-term Vertically Integrate Moisture Flux Divergence (VIMFD, $\left.-3.28 \times 10^{-5} \mathrm{~kg} \mathrm{~m}^{-2} \mathrm{~s}^{-1}\right)$, negative anomalous VIMFD $\left(-1.78 \times 10^{-5} \mathrm{~kg} \mathrm{~m}^{-2} \mathrm{~s}^{-1}\right)$ in $\mathrm{SWM}_{\text {Wet }}$ years and positive anomalous VIMFD $\left(1.44 \times 10^{-5} \mathrm{~kg} \mathrm{~m}^{-2} \mathrm{~s}^{-1}\right)$ in $\mathrm{SWM}_{\text {Dry }}$ years are recorded, which ascribed above-average and below-average rainfall over the country. Furthermore, strong moisture convergence (divergence) center in the western/ southwestern part of Sri Lanka during the $\mathrm{SWM}_{\mathrm{Wet}}\left(\mathrm{SWM}_{\text {Dry }}\right)$ years explain why strong positive and negative SWM rainfall anomalies are concentrated in these two regions. Furthermore, results highlighted a strong relationship between net moisture flux availability and SWM rainfall (r= 0.63 ) that may explain the observed SWM rainfall variability over the country.

Keywords: Southwest monsoon, wet and dry monsoon years, moisture flux, moisture convergence, Arabian Sea 


\section{Introduction}

According to Clausius-Clapeyron relation, moisture-holding capacity is increased by approximately 7\% with degree temperature rise (Wasko et al. 2018), which implies that the ability to hold moisture in the atmosphere is increased under the warming climate. As a consequence, enhance moisture content in the atmosphere and continuous transport of huge amounts of water vapor and its associated convergence intensify the occurrence and of heavy rainfall events (Liu et al. 2020; O’Gorman 2015; Rayner and Chen 2010). For instance, Rajeevan et al. (2008) found that the increase of the extreme rainfall events over central India is directly associated with an increase in the moisture content due to the rapid warming of the equatorial Indian Ocean. On the other hand, less moisture transport for long periods and large horizontal moisture flux divergence are the main causes to occur drought (Held and Soden 2006). These prompt extreme rainfall events cause flooding landslides, soil erosion (Trenberth et al. 2003), and high streamflow (Neiman et al. 2013).

In tropical and subtropical regions, Low-level jet (LLJ) systems and atmospheric rivers (ARs) are two major mechanisms of atmospheric moisture transport. LLJs can be defined as the wind corridors of the lower atmosphere, which carry moisture transport from warm oceans toward continental areas or low to high latitudes (Gimeno et al. 2016). In the Indian subcontinent, the strengthening of monsoon LLJ brought large-scale advection of moisture is a prerequisite for heavy rainfall (Xavier et al. 2018). On the other hand, a decrease in the strength of cross-equatorial LLJ exists over the Indian Ocean is favourable for drought development (Joseph and Simon 2005). Based on these facts, wind convergence and water vapor advection by monsoon flow are playing a significant role in moisture convergence or divergence over the Indian monsoon region. 
Southwest Monsoon (SWM) over the Indian monsoon region is generally termed as the Indian Summer Monsoon (ISM) (Dar and Ghosh 2017) and considered as one of the most active components of the climate system as part of the large-scale Asian monsoon (AM) circulation system (Kathayat et al. 2016). The availability of moisture transported from the warm waters of the Arabian Sea and Bay of Bengal (Turner and Annamalai 2012), high moisture convergence over the monsoon trough (Pathak et al. 2017), and the effects of topography (Konwar et al. 2012; Turner and Annamalai 2012) play a key role to originate the SWM rainfall over the landmass. Meanwhile, cross-equatorial moisture flux provides an important source of moisture for the SWM rainfall (Kathayat et al. 2016; Konwar et al. 2012; Ullah and Gao 2012). For instance, Roxy et al. (2017) quantify the total moisture contribution for extreme rainfall events in India and found that moisture comes from the Arabian Sea, the Bay of Bengal, and the central Indian Ocean contribute to $36 \%, 26 \%$, and $9 \%$ of the, respectively. In addition, the moisture already in the atmosphere, and local surface evaporation, also contributing to SWM rainfall variability (Wang et al. 2017).

Rayner and Chen (2010) and Trenberth (1999) revealed that moisture contribution to the heavy and moderated rainfall events are associated with large distance transport, not from local evaporation. For example, during the strong monsoon years, SWM rainfall is characterized by stronger south-westerly LLJ, such as the Somali jet from the Arabian Sea, which directed more moisture into the Indian subcontinent between latitudes $5^{\circ} \mathrm{N}$ to $15^{\circ} \mathrm{N}$. According to Joseph and Sijikumar (2004), the core of LLJ from the Arabian Sea has moved through $15^{\circ} \mathrm{N}$ during the active monsoon season. However, the LLJ has split into two branches during the break monsoon spell. The northern branch of the LLJ is at around $25^{\circ} \mathrm{N}$, while the southern branch move moves south-eastward in the latitude belt from the $10^{\circ} \mathrm{N}$ to the equator (close to Sri Lanka). Based on these facts, the movement of the LLJ from the Arabian Sea has a different influence on SWM rainfall in Sri Lanka and the Indian 
subcontinent. Interestingly we found that most of the floods and droughts are reported during the wet and dry SWM years, respectively. Therefore, the role of anomalies in the transport of moisture and moisture convergence/divergence during the contrast SWM years is helpful in understanding the causes of floods and droughts and of ongoing hydroclimate change.

Up to date, the role of moisture transport and the influence on this oceanic teleconnection with contrast SWM years over Sri Lanka is not well understood. Therefore, we have focused on identifying the abnormal water vapor transport pattern associated with moisture transport during the relatively wet and dry SWM years over Sri Lanka. The rest of the paper is organized as follows: Section 2 describes the general characteristics of the study area, data, and methodology. Section 3 is allocated for the result. Section 4 presents the discussion and conclusion of the study.

\section{Study site, Data, and Methodology}

\subsection{Study Site}

Sri Lanka is a tropical island country lying $\left(5^{\circ} 55^{\prime} \sim 9^{\circ} 51^{\prime} \mathrm{N}\right.$ and $\left.79^{\circ} 41^{\prime} \sim 81^{\circ} 53^{\prime} \mathrm{E}\right)$ in the Indian Ocean and located in the path of the Indian monsoons circulation. The rainfall pattern in Sri Lanka is seasonally well distributed due to the movement of the intertropical convergence zone (ITCZ) over the equatorial region. As a result, seasonal variation in rainfall is strongly impacted by the southwest monsoon (SWM: June-September) and the northeast monsoon (NEM: December to February). In between two monsoon periods, the first intermonsoon (FIM: March to May) and second inter-monsoon (SIM: October-November) seasons are identified (Malmgren et al. 2003). Three climatic zones are known as the wet zone, intermediate zone, and the semiarid dry zone, have been well-demarcated (Figure 1a) based on the regional differences in the amount of rain, seasonality, and variability (Rubasinghe et al. 2015). In addition, winds, temperature, relative humidity, and other 
climatic elements also show significant differences between the three climate zones. The mean annual temperature in Sri Lanka demonstrates largely homogeneous temperatures in the lowlands. The mean annual average temperature is $27^{\circ} \mathrm{C}$ from the lowlands, up to an altitude of $100-150 \mathrm{~m}$. The temperature is abruptly decreasing as the altitude increases in the highlands. For instance, the mean annual temperature at an altitude of about $1800 \mathrm{~m}$ is $15^{\circ} \mathrm{C}$ (Marambe et al. 2015).
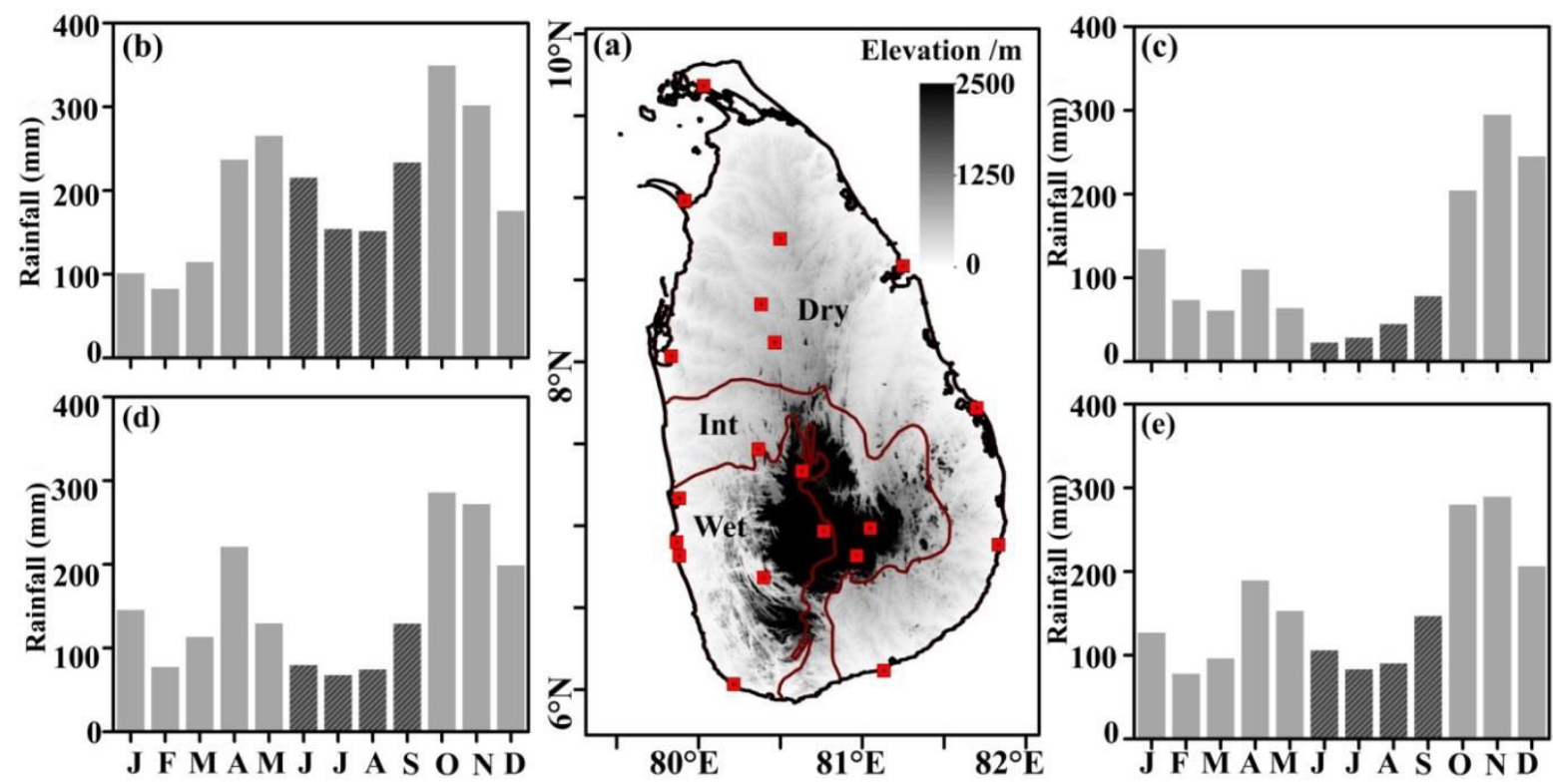

$80^{\circ} \mathbf{E}$

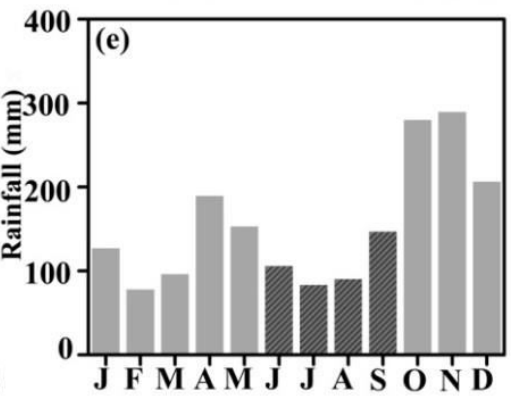

(a) The spatial distribution of meteorological stations (red squares) on the topographic map of Lanka. The seasonal cycle of rainfall (unit: $\mathrm{mm} / \mathrm{month}$ ) for (b) wet, (c) dry (d) intermediate zones. (e) is same as (b) but for the whole country. The thick shaded bars represent the months belong to the southwest monsoon season (SWM; June-September).

\subsection{Data}

Monthly rainfall data for 20 metrological stations ranging from 1985 to 2015 were collected from the Department of Meteorology Sri Lanka. According to geographical distribution, 7, 3, and 10 metrological stations are located in the wet, intermediate, and dry climate zones, respectively (Figure 1a). In addition, GPCC V6 data set with $0.5^{\circ} \times 0.5^{\circ}$ grid resolution were obtained from the Global Rainfall Climatology Centre (Schneider et al. 
2011), covering the study period for investigating the spatial distribution of rainfall anomaly in contrasting SWM years. For reproducing and interpreting the atmospheric branch of the hydrological cycle, ERA-Interim (ERA-I) reanalysis data (Dee et al. 2011), more specifically, four times daily zonal and meridional wind, specific humidity, and surface pressure with $0.5^{\circ}$ $\times 0.5^{\circ}$ grid resolution data set have been used.

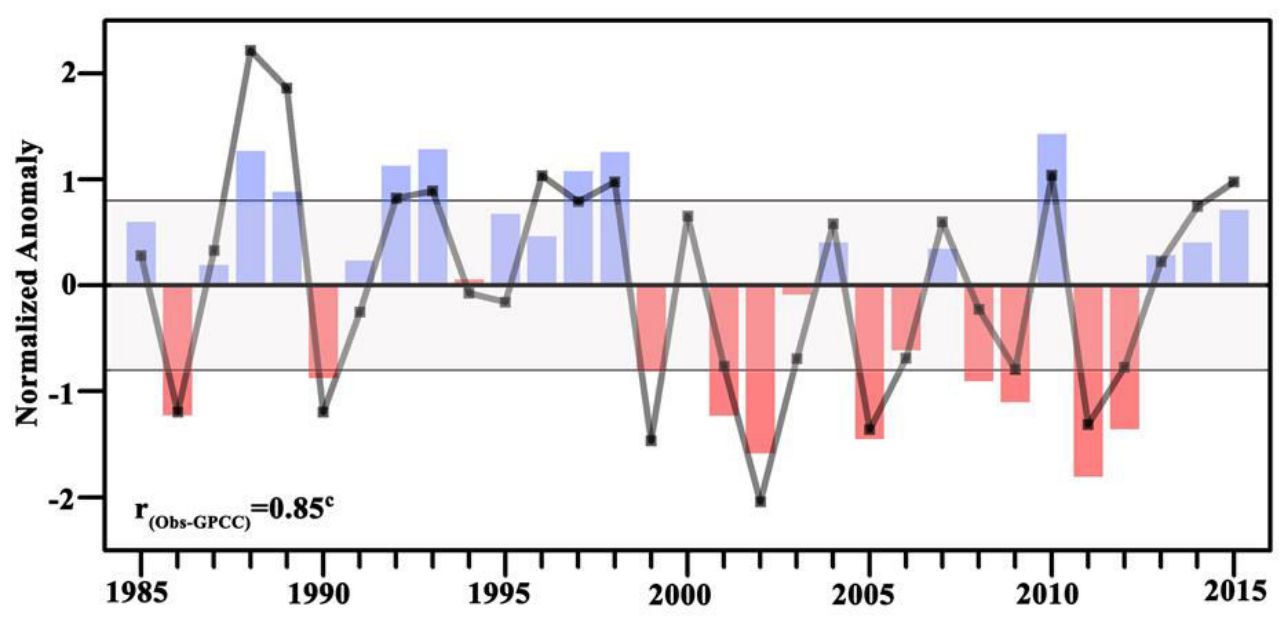

Figure 2 Temporal evolution of normalized southwest monsoon (SWM) rainfall using station observation (bar graph) and GPCC data set (line graph) for the 1985-2015 period. The shaded strip depicts the selected threshold value $( \pm 0.8)$ to select the set of $\mathrm{SWM}_{\mathrm{Wet}}$ and $\mathrm{SWM}_{\text {dry }}$ years. The positive and negative normalized rainfall anomalies are shown in light blue and pink clour, respectively. The letter "c" indicates the statistically significant

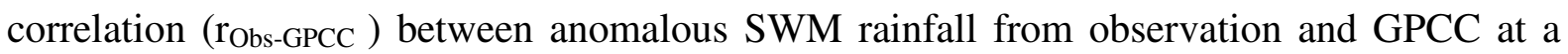
$99 \%$ confidence level.

\subsection{Methodology}

In this study, we used composite sampling techniques for identifying the relatively wet and dry rainfall years. For this purpose, we first calculated area average rainfall using station-based observation using the Thiessen polygon (TP) method with the elevation regression method (Limin et al. 2015; Shelton and Lin 2019). Apart from that, we calculated 
the area average SWM rainfall using the GPCC data. In the next stage, we derived normalized anomalous SWM rainfall time series and applied it to identify relatively wet and dry rainfall years, as follows. If the normalized SWM rainfall anomaly is above the +0.8 , it was identified as a relatively wet SWM (hereinafter $\mathrm{SWM}_{\mathrm{Wet}}$ ) year. In contrast, a relatively dry SWM (hereinafter $S_{W} M_{\text {Dry }}$ ) year is defined if the normalized anomaly is below -0.8 threshold levels in a particular year (Figure 2). Finally, eight wet and nine dry SWM years were selected for further analysis (Table 1). Notably, we found that the SWM rainfall anomaly from GPCC well produces the interannual variation of SWM rainfall in Sri Lanka (Figure 2) with a high correlation coefficient $\left(\mathrm{r}_{\mathrm{GPCC}-\mathrm{Observed}}=0.85\right)$. Therefore, we used GPCC data to display the spatial rainfall climatology and anomalous rainfall distribution in $\mathrm{SWM}_{\mathrm{Wet}}$ and SWM Dry years.

Table 1 The relatively wet $\left(\mathrm{SWM}_{\mathrm{Wet}}\right)$ and dry $\left(\mathrm{SWM}_{\mathrm{Dry}}\right)$ southwest monsoon(SWM) years from 1985 to 2015 .

\section{Season Condition Selected Year}

\begin{tabular}{lllllllllll}
\hline & SWM $_{\text {Dry }}$ & 1986 & 1990 & 1999 & 2001 & 2002 & 2005 & 2009 & 2011 & 2012 \\
SWM & & & & & & & & & & \\
& SWM $_{\text {Wet }}$ & 1988 & 1989 & 1992 & 1993 & 1997 & 1998 & 2010 & &
\end{tabular}

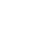

In this study, the top layer of vertical integration is considered at $300 \mathrm{hPa}$ because the specific humidity above $300 \mathrm{hPa}$ level is very low. According to (Ratna et al. 2016), moisture transports above $300 \mathrm{hPa}$ levels are a negligible influence on the calculation of Vertically Integrated Moisture Flux (VIMF).

$\operatorname{VIMF}(\vec{Q})$ in the troposphere from the surface to $300 \mathrm{hPa}$ is calculated using Eq.l. 


$$
\vec{Q}=\frac{1}{g} \int_{300}^{P s} q \vec{V} d p
$$

167 The zonal $\left(Q_{\varphi}\right)$ and meridional $\left(Q_{\gamma}\right)$ components of the VIMF are calculated using Eq.2 and 168 Eq.3, respectively.

$$
\begin{aligned}
& Q_{\varphi}=\frac{1}{g} \int_{300}^{P s} q u d p \ldots \ldots \ldots \ldots \ldots \ldots . . . . . . . . .2 q .2 \\
& Q_{\gamma}=\frac{1}{g} \int_{300}^{P s} q v d p \ldots \ldots \ldots \ldots \ldots \ldots E q .3
\end{aligned}
$$

169 Vertically Integrated Moisture Flux Divergence (VIMFD; $\nabla . \vec{Q}$ ) was computed using Eq.4

170 (Trenberth and Guillemot 1998):

$$
\nabla \cdot \vec{Q}=\nabla \cdot \frac{1}{g} \int_{300}^{P s} q \vec{V} d p \ldots \ldots \ldots \ldots q .4
$$

To understand the water vapor transports cross the four boundaries $(F v)$, Eastern boundary: $5^{\circ} \mathrm{N} \sim 10^{\circ} \mathrm{N}$ (at $82^{\circ} \mathrm{E}$ ), western boundary: $5^{\circ} \mathrm{N} \sim 10^{\circ} \mathrm{N}$ (at $79.5^{\circ} \mathrm{E}$ ), southern boundary: $79.5^{\circ} \mathrm{E} \sim 82^{\circ} \mathrm{E}\left(\right.$ at $5^{\circ} \mathrm{N}$ ) and northern boundary: $79.5^{\circ} \mathrm{E} \sim 82^{\circ} \mathrm{E}$ (at $10^{\circ} \mathrm{N}$ ) were defined, and the following equation (Eq.5) is used to calculate the moisture transport across a 175 wall.

$$
F v=\frac{1}{g} \int_{300}^{P s} \int_{0}^{l} q V d p d l \ldots \ldots \ldots \ldots . . . . .5 q
$$

176 The vertical distribution of regional moisture fluxes via each lateral boundaries are calculated 177 as follow,

$$
\vec{Q}=q \times \vec{V} \ldots \ldots \ldots \ldots \ldots \ldots .6 .6
$$

178 Where $g, q, P s, \vec{V}, u, v$, and $l$ are the acceleration of gravity, specific humidity, surface pressure horizontal wind vector, zonal wind, meridional wind, and a horizontal distance of section, respectively. The regional moisture budget is calculated as the net effect of moisture 
flux via each boundary. The positive regional moisture budget represented atmospheric water vapor transport from outside and converged within the region.

\section{$3 \quad$ Results}

\subsection{Southwest Monsoon Rainfall in Sri Lanka}

The seasonally varying monsoon system and the associated air masses and planetary wind regimes over South Asia have a great influence on the rainfall climate of Sri Lanka (Lin and Shelton 2020; Ranatunge et al. 2003). In this section, we take a closer look at the SWM rainfall contribution to annual total rainfall in different climate zones in Sri Lanka. As shown in Figure 1b, SWM rainfall contributes by $31.6 \%$ to the annual total rainfall $(2382 \mathrm{~mm})$ in the wet zone. For the intermediate zone, the annual total rainfall is $1974 \mathrm{~mm}$, where it gets $19.3 \%$ during the SWM season (Figure 1d). The annual total rainfall in the dry zone is $1360 \mathrm{~mm}$; out of that, $13 \%$ of rainfall receives from the SWM season (Figure 1c). When we consider the whole country average, the SWM rainfall contributes $23.1 \%$ to annual total rainfall (1845 $\mathrm{mm}$ ) (Figure 1e). Furthermore, the spatial distribution of SWM rainfall climatology for 19852015 is shown in Figures 3a. As shown in Figure 3a, southwestern and southern parts of the country (wet zone) receive more rainfall from the SWM season. The observed spatial and temporal variability of SWM rainfall is associated with regional and local topographic influences. For instance, the central highlands of the country (Figure.1a) acts as an important physiographical climatic barrier that controls the prevailing moisture-laden monsoon winds by generating 'fohn effect weather conditions' among regions (Lin and Shelton 2020). Similarly, the South Asian monsoon is a fully coupled ocean-land-atmosphere system, which is also affected by fixed orography (Turner and Annamalai 2012). As an example, the contribution from the western Indian Ocean to the ISMR is limited due to the Western Ghats (Pathak et al. 2017), even most of the rainwater discharging during the IMSR is originated 
over the ocean (Ordóñez et al. 2012). In addition, Shashikanth et al. (2014) revealed that the west coast and northeast India receive more precipitation during the summer monsoon because of the orographic effects of the Western Ghats and the Himalayas.

\subsection{Monsoon rainfall distribution in relatively wet and dry years}

In this section, we present the spatial distribution of anomalous rainfall distribution

SWM during the two contrast monsoon years (Figures 3b-c). Notably, we found that the whole domain receives above-average rainfall in $\mathrm{SWM}_{\mathrm{Wet}}$ years, while large positive anomalous rainfall is more concentrated on the western and southwestern parts of the country (Figure 3b). According to the long-term climatological mean (1985-2015), the seasonal average SWM rainfall in the wet, intermediate, and dry climate zones is $188 \mathrm{~mm}, 89 \mathrm{~mm}$, and $42 \mathrm{~mm}$, respectively. We observed that the rainfall amount in wet, intermediate, and dry zones is increased by $21.2 \%, 24.1 \%, 22.5 \%$ during the $\mathrm{SWM}_{\mathrm{Wet}}$ years, respectively (Table 2). Figure $3 \mathrm{c}$ shows that the whole country experienced below-average rainfall during the and September than the initial two months of the SWM season (Table 2). 


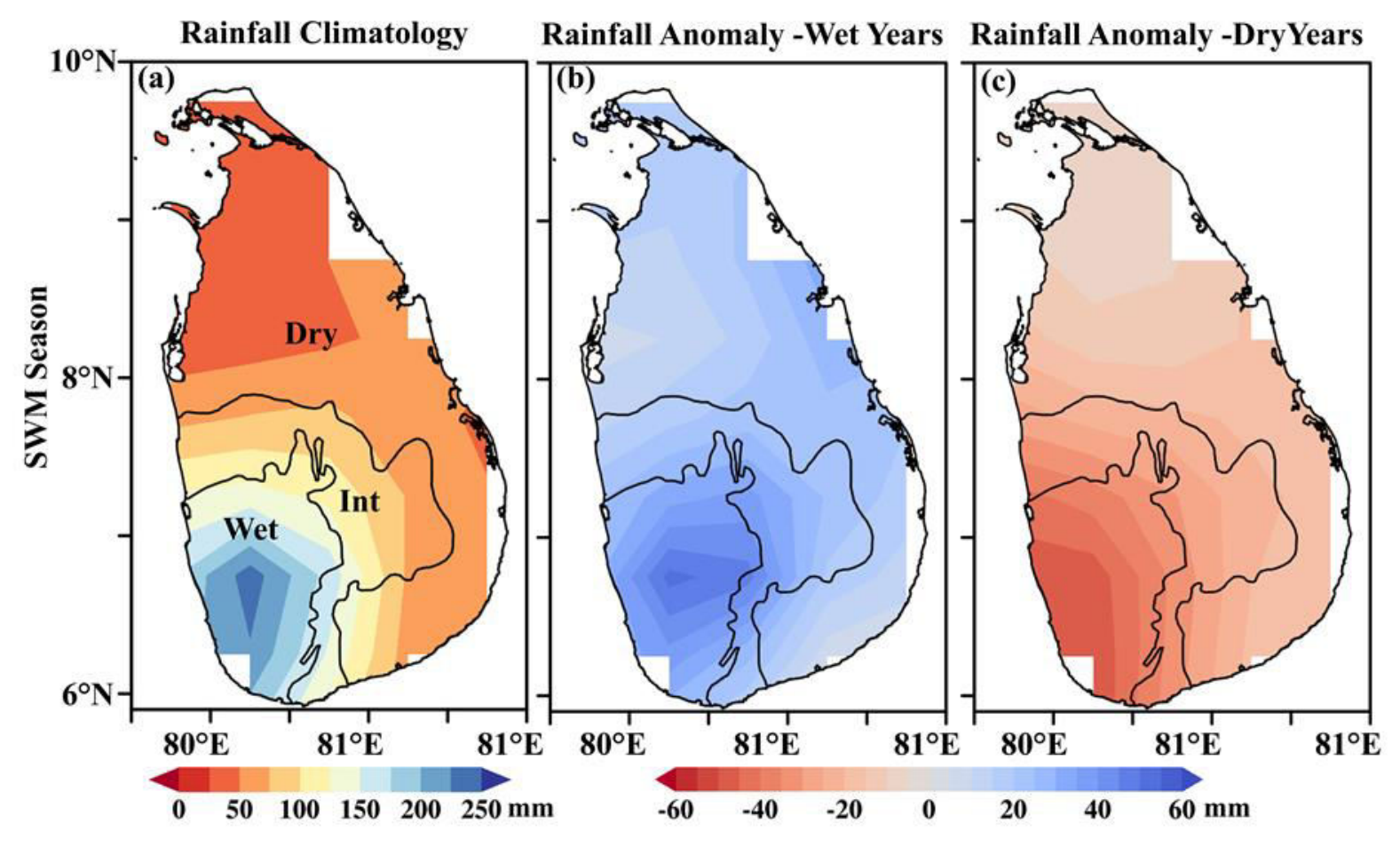

Figure 3 Spatial distribution of southwest monsoon (SWM) rainfall (a) climatology (mm/month) from 1985 to 2015 and anomalous SWM rainfall (mm/month) for a set of relatively (b) wet and (c) dry SWM years. The wet, intermediate, and dry climate regions are demarcated by black lines and named as Wet, Int, and dry.

In $\mathrm{SWM}_{\mathrm{Wet}}$ years, the monthly mean rainfall over the wet zone increased by $22.2 \%$, $39.5 \%$, and $20.6 \%$ in June, July, and September, respectively. In contrast, all months of the season showed rainfall subsidence during the $\mathrm{SWM}_{\text {Dry }}$ years, where the most considerable rainfall reduction is observed in June (32.2\%) and September (34\%) concerning the longterm mean value of the monthly rainfall. Similarly, results show that both dry and 240 intermediate zones show a percentage increase (decrease) in monthly rainfall for $\mathrm{SWM}_{\mathrm{Wet}}$ $241\left(\mathrm{SWM}_{\text {Dry }}\right)$ years. For instance, in $\mathrm{SWM}_{\text {Wet }}$ years, the July rainfall is increased by $70.8 \%$ over the intermediate and $85.2 \%$ over dry zones, respectively. In contrast, the largest rainfall subsidence over intermediate and dry zones is observed June (45.9\%) and July (42.0\%) (Table 2). 
Table 2 The monthly and seasonal average rainfall for the long-term climatology $(\mathrm{mm})$, and percentage change $(\%)$ of the rainfall from the long-term mean value for relatively wet

$247\left(\mathrm{SWM}_{\mathrm{Wet}}\right)$ and dry SWM (SWM $\left.\mathrm{Sry}\right)$ years. The Wet, Int, and Dry denote three climate zones 248 in Sri Lanka.

\begin{tabular}{|c|c|c|c|c|c|c|}
\hline Zones & Condition & June & July & August & September & SWM \\
\hline \multirow{3}{*}{ Wet } & Average (mm) & 214.3 & 154.5 & 151.6 & 232.7 & 188.3 \\
\hline & $\mathrm{SWM}_{\text {Wet }}(\%)$ & 22.2 & 39.5 & 2.2 & 20.6 & 21.2 \\
\hline & SWM $_{\text {Dry }}(\%)$ & -32.4 & -25.5 & -26.4 & -34.1 & -30.3 \\
\hline \multirow{3}{*}{ Int } & Average (mm) & 80.9 & 72.1 & 74.7 & 129.2 & 89.2 \\
\hline & $\operatorname{SWM}_{\text {Wet }}(\%)$ & 21.0 & 70.8 & 18.7 & 3.0 & 24.1 \\
\hline & $\mathrm{SWM}_{\text {Dry }}(\%)$ & -45.9 & -17.7 & -13.4 & -29.7 & -27.5 \\
\hline \multirow{3}{*}{ Dry } & Average (mm) & 26.4 & 25.6 & 43.9 & 73.8 & 42.4 \\
\hline & $\operatorname{SWM}_{\text {Wet }}(\%)$ & 3.9 & 85.2 & 22.0 & 7.7 & 22.5 \\
\hline & SWM $_{\text {Dry }}(\%)$ & -35.4 & -42.0 & -22.9 & -40.4 & -35.3 \\
\hline
\end{tabular}

249

250

251

252

253

254

255

256

257

Meanwhile, we investigate spatial variation of rainfall in months of the SWM season.

Figures 4a-d show the spatial distribution of rainfall climatology (1985-2015) for June, July, August, and September, while the middle (Figures 4a1-d1) and lower (Figures 4a2-d2) panels depict the anomalous rainfall in each month for $\mathrm{SWM}_{\mathrm{Wet}}$ and $\mathrm{SWM}_{\text {Dry }}$ years, respectively. Notably, we found that all the months of the SWM season bring a considerable amount of rainfall over the wet zone, where the rainfall peaks are observed in June and September. In general, the intermediate and dry zones receive less than $100 \mathrm{~mm}$ rainfall in individual months of the season except for September (Figures 4a-d). 


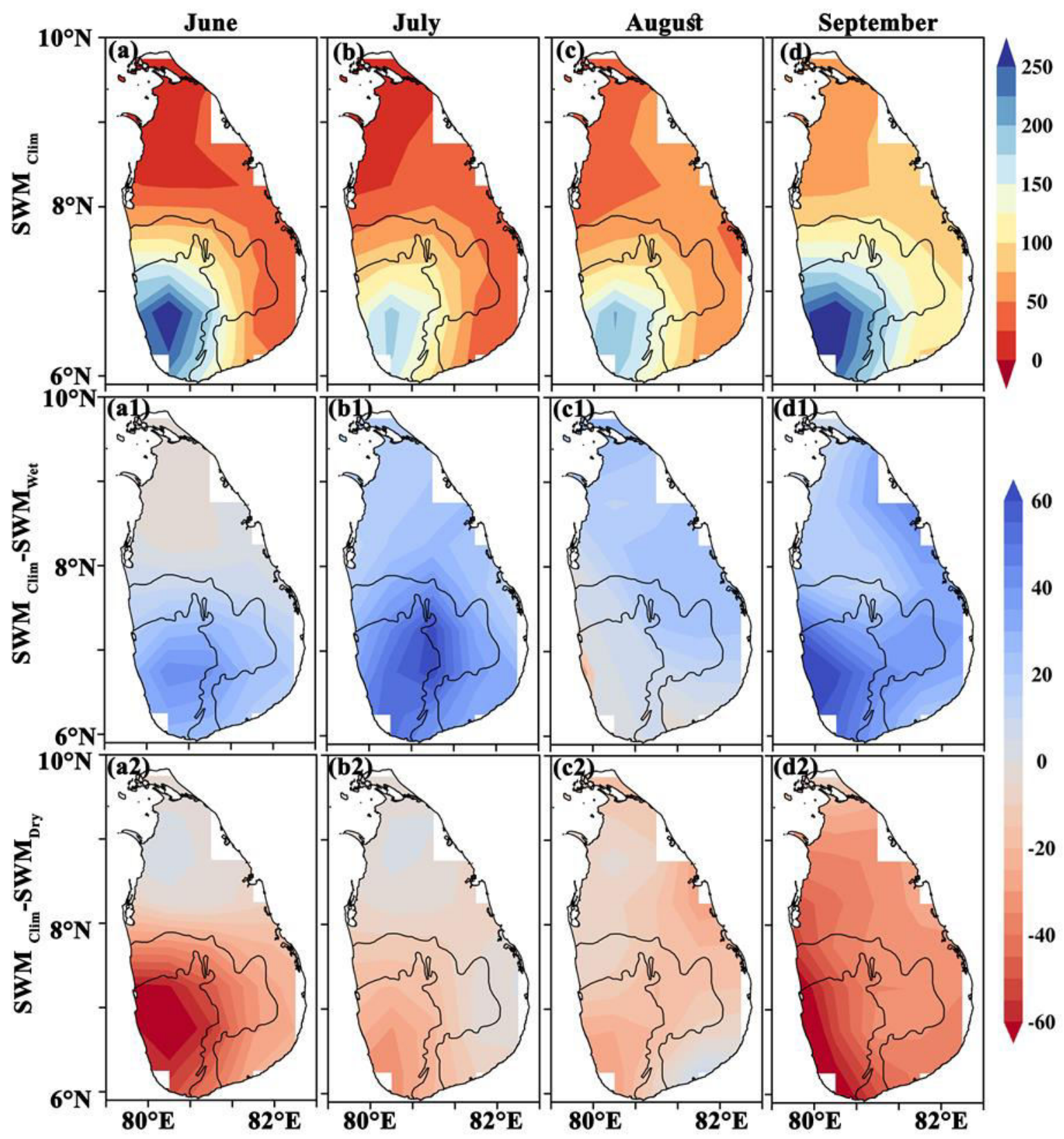

Figure 4 Spatial distribution of rainfall (unit; $\mathrm{mm}$ ) for a long-term average (SWM $\mathrm{Slim}_{\text {; }}$;

261 1985-2015) of the (a) June, (b) July, (c) August, and (d) September. The middle (a1-d1) and 262 right (a2-d2) columns are the same as the left column but for the anomalous rainfall for relatively (b) wet $\left(\mathrm{SWM}_{\mathrm{Wet}}\right)$ and (c) dry $\mathrm{SWM}\left(\mathrm{SWM}_{\text {Dry }}\right)$ years.

During $\mathrm{SWM}_{\mathrm{Wet}}$ years, all months of the season showed above-average rainfall, while strong positive anomalous rainfall is observed in July and September. The other remarkable feature of Figures 4a1-d1 is most of the positive anomalous rainfall is concentrated in the wet 
zone except August in the SWM season. In SWM Dry years, strong negative anomalous rainfall is observed in June and September, while it is localized to the wet zone (Figures 4a2-

d2). In order to investigate the possible reason for the above-average and below-average rainfall in the SWM season, the moisture transports and associated moisture flux divergence/convergence in $\mathbf{S W M}_{W e t}$ and $\mathbf{S W M}_{\text {Dry }}$ years have been analyzed in the next section.

\subsection{Vertically Integrated Moisture Flux and its Divergence}

According to Trenberth et al. (2003) and Gao and Sun (2016), the ascending motion, the microphysics inside cloud droplets, and moisture supply determine whether rainfalls or not in a particular region. It is noticed that the large-scale convergence rather than locally enhanced evaporation controls the precipitation patterns in the tropics (Allan and Soden 2007; Trenberth et al. 2003). Therefore, analysis of the moisture transport and its divergence/ convergence provides insights into the major modes of precipitation variability over the country, as well as the moisture sources themselves. Therefore, climatological vertical integrated moisture flux (VIMF; vector) over Sri Lanka is investigated to understand the water vapor supply towards the country in the SWM season (Figures 5a). In the same figure, we display the climatological vertically integrated moisture flux divergence (VIMFD; shaded).

As shown in figure 5a, the VIMF vector from the Arabian Sea direction supplied moisture towards the convention center over Sri Lanka. Similarly, Pathak et al. (2017) found that moisture flux from the Western Indian Ocean (Arabian Sea) direction is the most important contributor for the initial phase of the Indian monsoon as compared to moisture flux from south of the equator direction. In the same study, they identify the regions with high vertically integrated moisture flux divergence as the potential sources of atmospheric moisture; meanwhile, regions with high convergence are considered as potential sink regions. 
292 Figure 5a also shows climatological mean moisture flux divergence (+ value) over the 293 Arabian Sea direction (source) as well as the Bay of Bengal, while more moisture convergence (- divergence) over the western and southwestern parts (sink) of the county during the SWM season. We further notice strong moisture divergence over the eastern and southeastern parts of the country.

In Figure 5b, we show the anomalous water vapor fluxes (vectors) and associated moisture flux divergence (shaded) for the $\mathrm{SWM}_{\mathrm{Wet}}$ years. Compared to the mean state, the excess moisture fluxes can be seen over the study region, and vectors move towards the South Indian sea direction. Furthermore, we detected cyclonic circulation of the VIMF over the Bay of Bengal and the northeastern part of the Arabian Sea during SWM $\mathrm{Wet}_{\text {years, which }}$ inject moisture-laden wind towards the country. In contrast, the weakening of the westerly transport moisture flux can be observed over Sri Lanka and most of the eastern part of the Arabian Sea during SWM Dry years (Figure 5c), which results in less moisture availability and ultimately it caused SWM rainfall subsidence over Sri Lanka. Similar to our findings, Ratna et al. (2014) found that the weakening of westerlies reduced the moisture transport towards the southern part of the Western Ghats as well as local precipitation over India. Levine and Turner (2012) also pointed out that the strongest monsoon in the Indian subcontinent depended heavily on the moisture flux of the Arabian Sea.

Furthermore, we observed considerable spatial variations in the anomalous moisture flux divergence during the $\mathrm{SWM}_{\mathrm{Wet}}$ and $\mathrm{SWM}_{\text {Dry }}$ years over Sri Lanka (Figure $5 \mathrm{~b}-\mathrm{c}$ ). For instance, an area with negative anomalous divergence has been observed over the western and southwestern parts of the country, while negative moisture flux divergence is observed over Western Ghats and Bay of Bengal as well in $\mathrm{SWM}_{\mathrm{Wet}}$ years (Figure 5b). In $\mathrm{SWM}_{\text {Dry }}$ years, all the study domain depicts positive divergence fluxes anomaly, while strong divergence centers are located over the western and southwestern parts of the country. 
Meanwhile, we further observed positive anomalous moisture flux divergence over the Bay of Bengal (Figure 5c). A closer look at the anomalous moisture divergence over Sri Lanka suggests that SWM rainfall is mostly concentrated over the western and southwestern parts of the country, which is attributed due to the influence of the central mountain of Sri Lanka. As a result, western and southwestern parts receive more (less) rainfall in $\mathrm{SWM}_{\mathrm{Wet}}\left(\mathrm{SWM}_{\text {Dry }}\right)$ years.
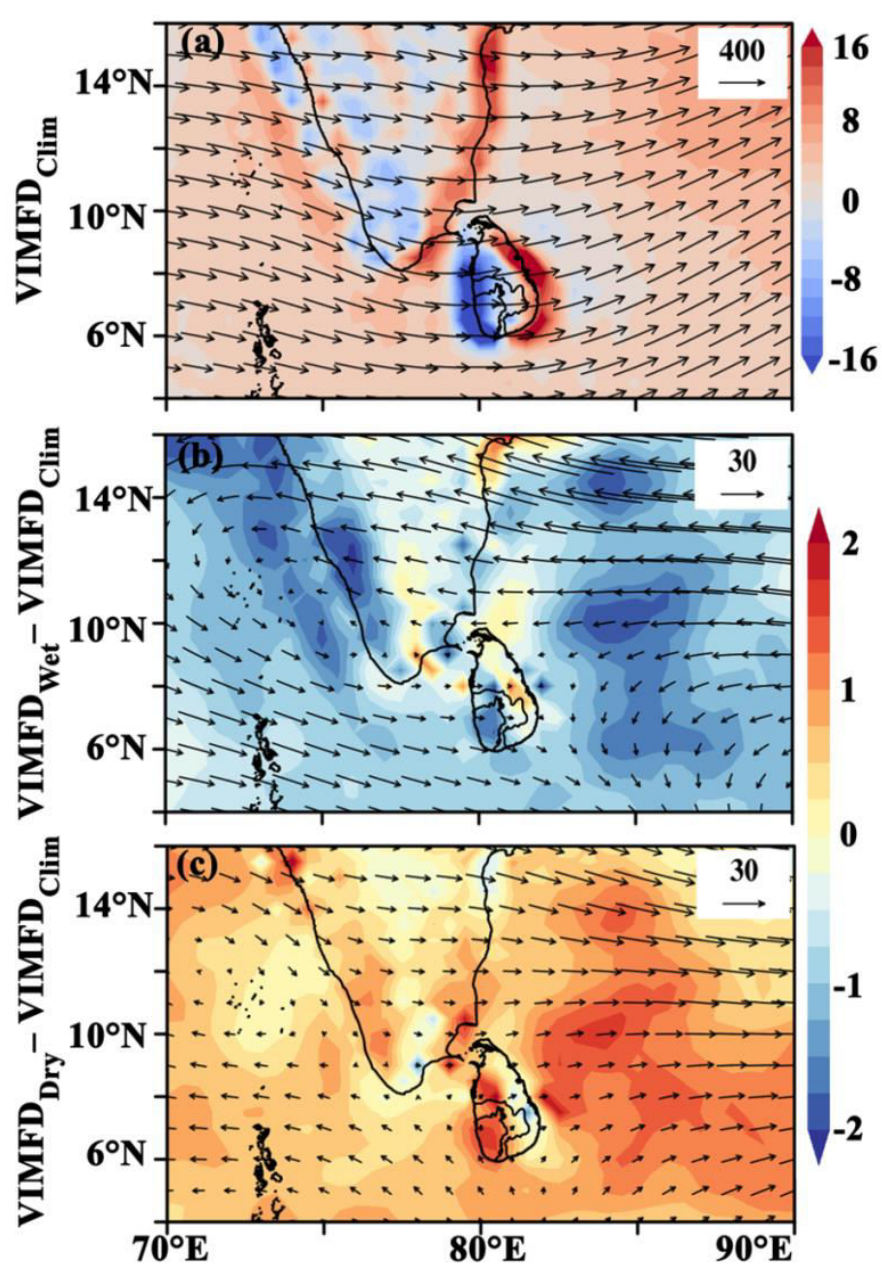

324 Figure 5 Vertically integrated moisture flux divergence (VIMFD, shaded, unit; $10^{-6} \mathrm{~kg}$ $325 \mathrm{~m}^{-2} \mathrm{~s}^{-1}$ ) superimposed with vertically integrated moisture flux (VIMF, vector, unit: $\mathrm{kg} \mathrm{m}^{-1} \mathrm{~s}^{-1}$ ) for (a) a long-term average of the southwest monsoon season (VIMFD ${ }_{\text {Clim }}$ ) and anomalies for relatively (b) wet $\left(\mathrm{SWM}_{\mathrm{Wet}}\right)$ and (c) dry $\mathrm{SWM}\left(\mathrm{SWM}_{\text {Dry }}\right)$ years. 

convergence/divergence over the study domain during the $\mathrm{SWM}_{\mathrm{Wet}}$ and $\mathrm{SWM}_{\text {Dry }}$ years through Sri Lanka towards the Bay of Bengal direction in all the months of the SWM season (June-September), while the strong moisture fluxes (vectors) is observed in June. Another remarkable feature we observed in this figure is strong moisture flux convergence over the western/southwestern parts and moisture divergence in the northeast and east parts of the country. The climatological VIMFD further shows that no significant difference in VIMFD among the month of the SWM season.

When we consider the VIMF anomaly in $\mathrm{SWM}_{\text {Wet }}$ years, all the months except August show above-average VIMF, while cyclonic circulation of VIMF is observed over the Arabian sea direction in June. In the $\mathrm{SWM}_{\mathrm{Wet}}$ years, the strong moisture flux convergence is observed near the Western Ghats and over the Bay of Bengal during the first two months of the season. Furthermore, we detected that strong moisture flux convergence over the south/southwestern parts of Sri Lanka in June, July, and September (Figures 6a1-b1 and d1), while the moisture flux convergence in August is less as compared with other months of the seasons (Figure 6c1).

In $\mathrm{SWM}_{\text {Dry }}$ years, we observe that the strength of the VIMF is reduced from JuneSeptember. As shown in Figures 6a2-c2, the strong moisture flux divergence is located over the Bay of Bengal in June, which is gradually decreasing up to August. Furthermore, we detected strong moisture flux divergence over the south/southwestern parts of Sri Lanka in $\mathrm{SWM}_{\text {Dry }}$ years, especially in September, where divergence is stronger than the other three months of the season (Figure 6d2). 

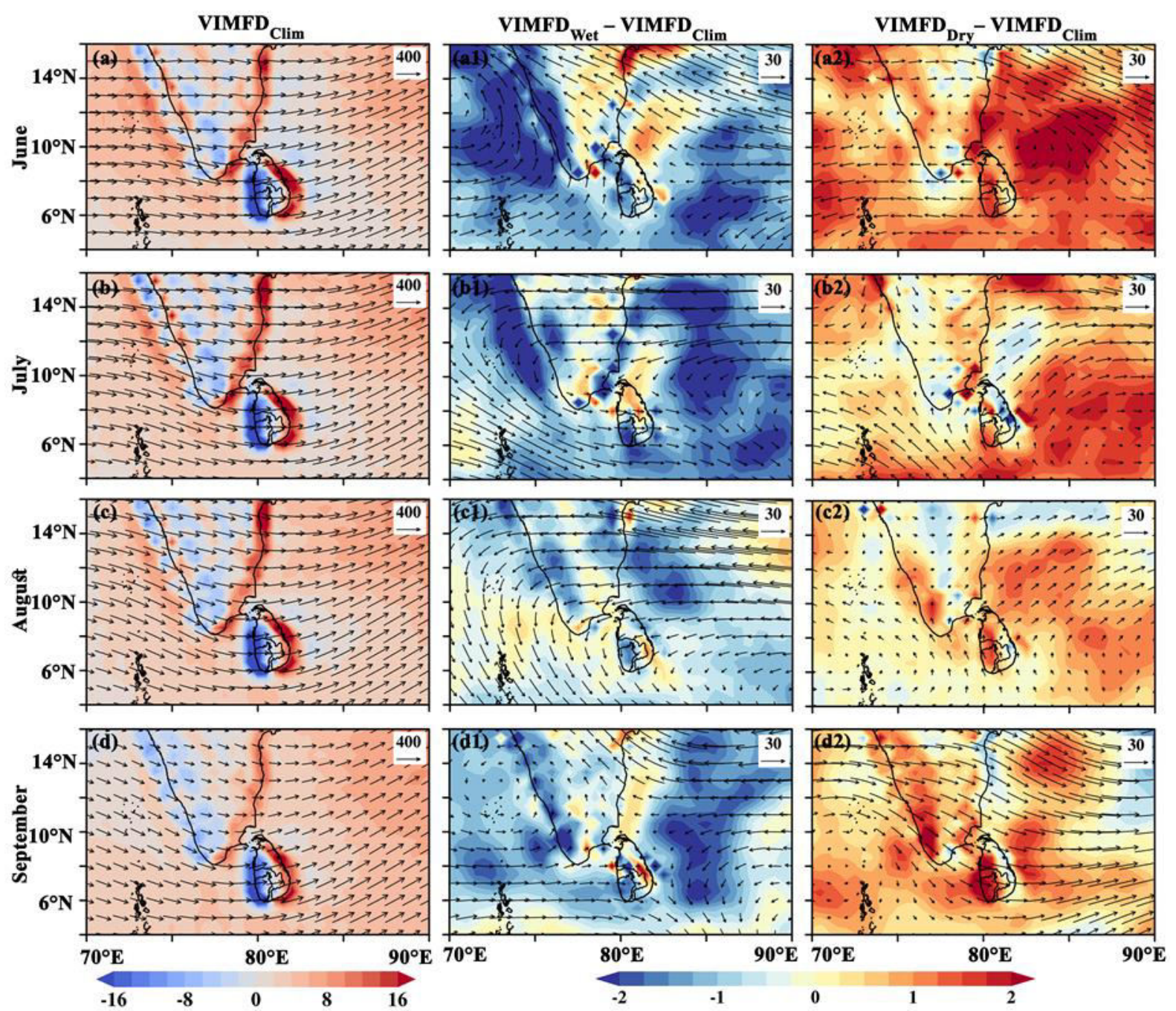

Figure 6 Vertically integrated moisture flux divergence (VIMFD, shaded, unit; $10^{-6} \mathrm{~kg}$ $354 \mathrm{~m}^{-2} \mathrm{~s}^{-1}$ ) superimposed with vertically integrated moisture flux (VIMF, vector, unit: $\mathrm{kg} \mathrm{m}^{-1} \mathrm{~s}^{-1}$ ) for a long-term average (1985-2015) of the (a) June, (b) July, (c) August, and (d) September.

356 The middle (a1-d1) and right (a2-d2) columns are the same as the left column but for the anomalous VIMFD and VIMF for relatively (b) wet $\left(\mathrm{SWM}_{\mathrm{Wet}}\right)$ and (c) dry SWM (SWM $\mathrm{Sry}_{\text {Dry }}$ years.

\subsection{Moisture Flux Through Different Boundaries}

In this section, we quantify the moisture transport via different boundaries and

361 investigate the anomalous moisture flux in $\mathrm{SWM}_{\mathrm{Wet}}$ and $\mathrm{SWM}_{\text {Dry }}$ years. In addition, The regional average net moisture flux is calculating by getting the difference of moisture influx 
and outflux from the different boundaries of the study domain. The long-term climatology of moisture transport from each boundary and associated anomalous moisture fluxes for $\mathrm{SWM}_{\mathrm{Wet}}$ and $\mathrm{SWM}_{\text {Dry }}$ years are depicted in Figures 7a-c. Based on the long-term climatology for moisture fluxes for SWM season, the western $\left(20.36 \times 10^{5} \mathrm{~kg} \mathrm{~s}^{-1}\right)$ and southern $\left(14.60 \times 10^{5}\right.$

$\left.367 \mathrm{~kg} \mathrm{~s}^{-1}\right)$ boundaries act as moisture influx boundaries, while eastern $\left(19.86 \times 10^{5} \mathrm{~kg} \mathrm{~s}^{-1}\right)$ and northern $\left(10.69 \times 10^{5} \mathrm{~kg} \mathrm{~s}^{-1}\right)$ boundaries are considered as the main moisture outflux boundaries (Figure 7a).
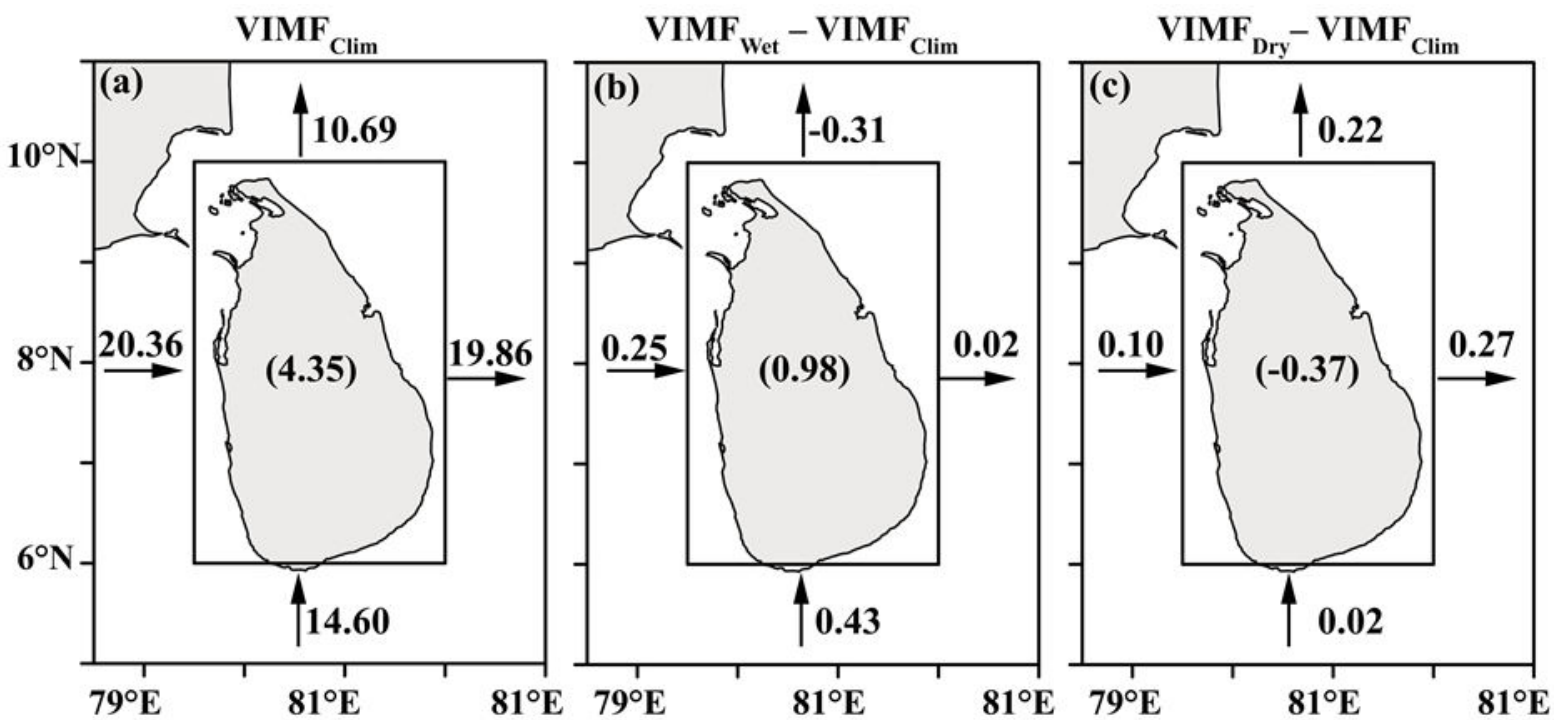

Figure 7 The vertically integrated moisture flux (VIMF) across the four different boundaries for (a) a long-term average of the southwest monsoon season $\left(\mathrm{VIMF}_{\mathrm{Clim}}\right)$, and anomalies for relatively (b) wet $\left(\mathrm{SWM}_{\mathrm{Wet}}\right)$ and (c) dry SWM (SWM $\left.\mathrm{Sry}_{\text {) }}\right)$ years. Dark arrows indicate the climatological direction of the moisture transport across the wall. The number in brackets indicates the net flux convergence (unit: $10^{5} \mathrm{~kg} \mathrm{~s}^{-1}$ ). The inner box shows the western $\left(6^{\circ} \mathrm{N} \sim 10^{\circ} \mathrm{N}\right.$ at $\left.79.5^{\circ} \mathrm{E}\right)$, eastern $\left(6^{\circ} \mathrm{N} \sim 10^{\circ} \mathrm{N}\right.$ at $\left.82^{\circ} \mathrm{E}\right)$, southern $\left(79.5^{\circ} \mathrm{E} \sim 82^{\circ} \mathrm{E}\right.$ at $\left.6^{\circ} \mathrm{N}\right)$ and northern $\left(79.5^{\circ} \mathrm{E} \sim 82^{\circ} \mathrm{E}\right.$ at $\left.10^{\circ} \mathrm{N}\right)$ boundaries. 
The anomalous moisture influx from the western and southern boundary during the $\mathrm{SWM}_{\mathrm{Wet}}$ years is $0.25 \times 10^{5}$ and $0.43 \times 10^{5} \mathrm{~kg} \mathrm{~s}^{-1}$, respectively. However, the amount of moisture influx decreased during the $S W M_{\text {Dry }}$ years; for instance, the influx anomaly for the

382 western boundary is $0.10 \times 10^{5} \mathrm{~kg} \mathrm{~s}^{-1}$ and $0.02 \times 10^{5} \mathrm{~kg} \mathrm{~s}^{-1}$ for the southern boundary. As a moisture outflux boundary, the eastern boundary reported $0.02 \times 10^{5} \mathrm{~kg} \mathrm{~s}^{-1}$ and $0.27 \times 10^{5} \mathrm{~kg} \mathrm{~s}^{-1}$ anomalous moisture flux for the $\mathrm{SWM}_{\mathrm{Wet}}$ and $\mathrm{SWM}_{\text {Dry }}$ years, respectively. At the same time, moisture outflux through the northern boundary showed a negative anomaly $\left(-0.31 \times 10^{5} \mathrm{~kg} \mathrm{~s}\right.$ $\left.{ }^{1}\right)$ during the $\mathrm{SWM}_{\mathrm{Wet}}$ years, while the positive anomaly $\left(0.22 \times 10^{5} \mathrm{~kg} \mathrm{~s}^{-1}\right)$ is observed in SWM $M_{\text {Dry }}$ years (Figures 7b-c). Similar to our findings, Ratna et al. (2014) found the main moisture influx and outflux for the Indian subcontinent are the southern boundaries of the Arabian Sea and the eastern boundary, respectively. Considering the moisture influx and outflux, the area-average net moisture budget (hereinafter, NetMB) for the 1985-2015 period over the study domain is $4.35 \times 10^{5} \mathrm{~kg} \mathrm{~s}^{-1}$. Figures $7 \mathrm{~b}$-c further show the positive NetMB anomaly $\left(0.98 \times 10^{5} \mathrm{~kg} \mathrm{~s}^{-1}\right)$ and negative NetMB anomaly $\left(-0.37 \times 10^{5} \mathrm{~kg} \mathrm{~s}^{-1}\right)$ in $\mathrm{SWM}_{\mathrm{Wet}}$ and $\mathrm{SWM}_{\text {Dry }}$ years, respectively.

Based on the results, we can explain the observed rainfall variability in relatively wet and dry monsoon years in terms of net moisture flux over the study domain. For instance, positive NetMB is one of the reasons for the relatively wet monsoon rainfall events over Sri Lanka. To further prove this, the relationship between seasonal rainfall anomalies over Sri Lanka and NetMB has been evaluated, as shown in Figures 8. For the SWM season, the normalized NetMB shows a statistically significant correlation with the normalized SWM rainfall anomaly calculated using station based observation $(r=0.63)$ and GPCC product $(r=$ 0.59) (Figure 8). 

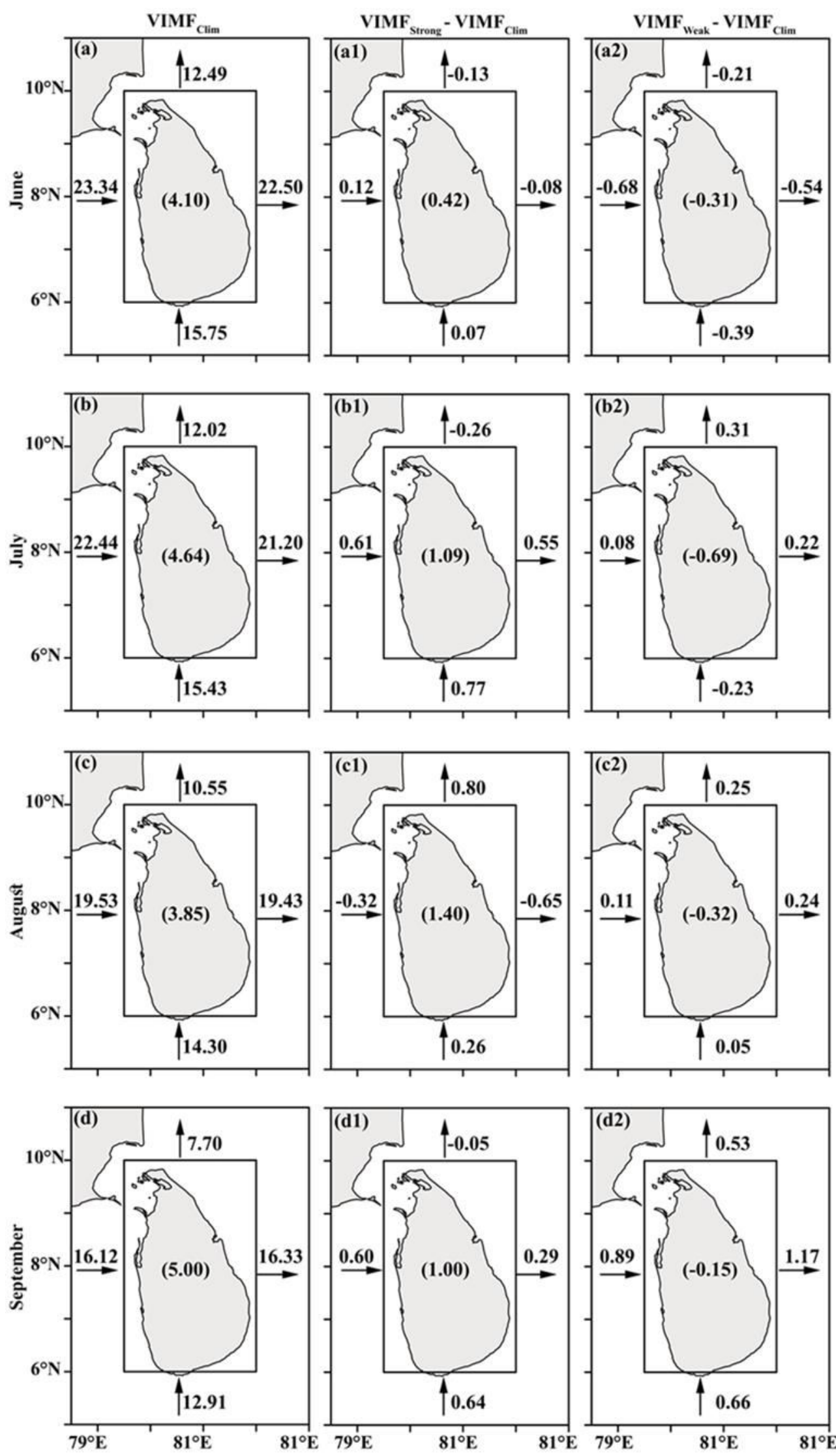
Figure 8 The vertically integrated moisture flux (VIMF) across the four different

404

405

406

407

408

409

410

411

412

413

414

415

416

417

418

419

420

421

422

423

424 boundaries in Sri Lanka for a long-term average of (a) June, (b) July, (c) August, and (d) September. The middle (a1-d1) and right (a2-d2) panels are the same as left panels but for the VIMF anomalies for relatively wet $\left(\mathrm{SWM}_{\mathrm{Wet}}\right)$ and dry SWM (SWM $\left.\mathrm{Sry}_{\mathrm{D}}\right)$ years, respectively. Dark arrows indicate the climatological direction of the moisture transport across the wall. The number in brackets indicates the net flux convergence (unit: $10^{5} \mathrm{~kg} \mathrm{~s}^{-1}$ ). The inner box shows the western $\left(6^{\circ} \mathrm{N} \sim 10^{\circ} \mathrm{N}\right.$ at $\left.79.5^{\circ} \mathrm{E}\right)$, eastern $\left(6^{\circ} \mathrm{N} \sim 10^{\circ} \mathrm{N}\right.$ at $\left.82^{\circ} \mathrm{E}\right)$, southern $\left(79.5^{\circ} \mathrm{E} \sim 82^{\circ} \mathrm{E}\right.$ at $\left.6^{\circ} \mathrm{N}\right)$, and northern $\left(79.5^{\circ} \mathrm{E} \sim 82^{\circ} \mathrm{E}\right.$ at $\left.10^{\circ} \mathrm{N}\right)$ boundaries.

We further analyze the NetMB in each month of the season, as depicted in Figure 9. The long-term climatology of the NetMB in June, July, August, and September are $4.10 \times 10^{5}$ $\mathrm{kg} \mathrm{s}^{-1}, 4.64 \times 10^{5} \mathrm{~kg} \mathrm{~s}^{-1}, 3.85 \times 10^{5} \mathrm{~kg} \mathrm{~s}^{-1}$, and $5.00 \times 10^{5} \mathrm{~kg} \mathrm{~s}^{-1}$, respectively (Figure 9a-d). Interestingly, we found that the western boundary is the main moisture influx in all the months. For instance, the large moisture influx via the western boundary is recorded in June $\left(23.34 \times 10^{5} \mathrm{~kg} \mathrm{~s}^{-1}\right)$, which is gradually decreasing with time (e.g., $16.12 \times 10^{5} \mathrm{~kg} \mathrm{~s}^{-1}$ in September).on the other hand southern boundary also act as moisture influx where the highest and lowest influxes are recorded in June $\left(15.75 \times 10^{5} \mathrm{~kg} \mathrm{~s}^{-1}\right)$ and September $\left(12.91 \times 10^{5} \mathrm{~kg} \mathrm{~s}^{-1}\right)$ respectively. In terms of magnitude, the eastern boundary act as a major outflux boundary for each month of the SWM season. Similar to the influx boundary, the outflux from the eastern boundary is decreasing with time; for instance, the outflux in June is $22.50 \times 10^{5} \mathrm{~kg} \mathrm{~s}^{-1}$, which decreased up to $16.33 \times 10^{5} \mathrm{~kg} \mathrm{~s}^{-1}$ in September. The northern boundary also acts as the outflux boundary where the largest outflux is recorded in June $\left(12.49 \times 10^{5} \mathrm{~kg} \mathrm{~s}^{-1}\right)$, while the lowest outflux $\left(7.70 \times 10^{5} \mathrm{~kg} \mathrm{~s}^{-1}\right)$ is detected in September (Figure 9a-d). 


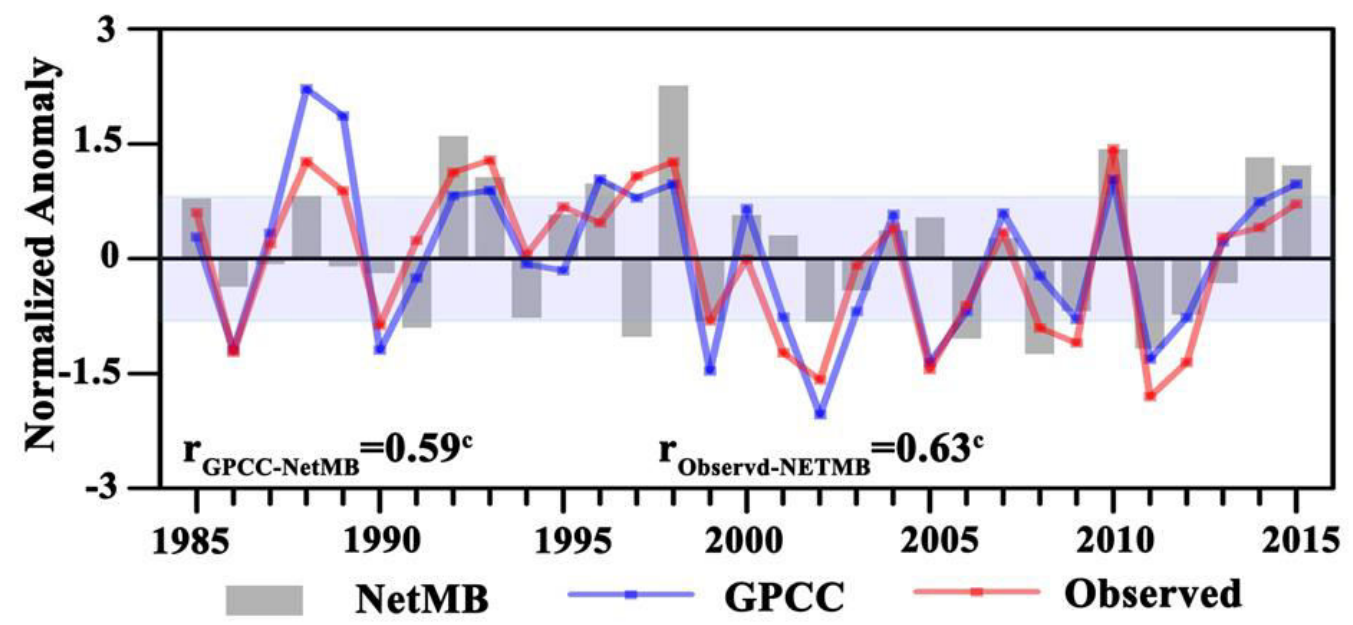

425

426

427

Figure 9 The correlation between normalized southwest monsoon (SWM) rainfall anomaly and net moisture budget (NetMB). The letter "c" shows a statistically significant correlation at a $99 \%$ confidence level. The rainfall anomaly is calculated using station observation (red line) and GPCC data product (blue line). The anomalous SWM rainfall anomalies are above and below the shaded strip are considered as relatively wet and dry SWM years, respectively.

In relatively wet SWM years, all months of the season showed positive anomalous NetMB with respect to the long-term climatology, as shown in Figures 9a1-d1, where the largest positive anomaly was observed in August $\left(1.40 \times 10^{5} \mathrm{~kg} \mathrm{~s}^{-1}\right)$ relative to the long-term mean. However, the largest NetMB is observed in September $\left(6.00 \times 10^{5} \mathrm{~kg} \mathrm{~s}^{-1}\right)$, followed by July $\left(5.73 \times 10^{5} \mathrm{~kg} \mathrm{~s}^{-1}\right)$, June $\left(4.52 \times 10^{5} \mathrm{~kg} \mathrm{~s}^{-1}\right)$, and August $\left(4.25 \times 10^{5} \mathrm{~kg} \mathrm{~s}^{-1}\right)$. Considering the moisture influx via western boundary, positive anomalous net moisture influx is observed in all the months except August, where the largest positive anomaly is recorded in July, which is quite similar to an anomaly in September. On the other hand, the southern boundary showed positive anomalous net moisture flux during all the months in the SWM season. With respect to the long-term mean influx from the southern boundary, June $\left(0.07 \times 10^{5} \mathrm{~kg} \mathrm{~s}^{-1}\right)$ and July $\left(0.77 \times 10^{5} \mathrm{~kg} \mathrm{~s}^{-1}\right)$ show the lowest and highest influx anomaly, respectively. The moisture outflux from the eastern boundary shows a negative anomaly in June $\left(-0.08 \times 10^{5} \mathrm{~kg} \mathrm{~s}^{-1}\right)$ and 
444 August $\left(-0.65 \times 10^{5} \mathrm{~kg} \mathrm{~s}^{-1}\right)$, while July $\left(0.55 \times 10^{5} \mathrm{~kg} \mathrm{~s}^{-1}\right)$ and September $\left(0.29 \times 10^{5} \mathrm{~kg} \mathrm{~s}^{-1}\right)$

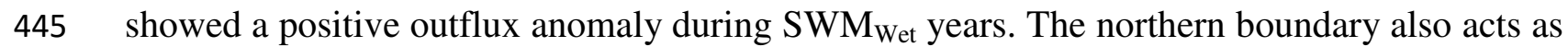
a moisture outflux boundary, where negative outflux anomalies are recorded all months except August $\left(0.29 \times 10^{5} \mathrm{~kg} \mathrm{~s}^{-1}\right)$.

In $\mathrm{SWM}_{\text {Dry }}$ years, the long-term mean of NetMB for June, July, August, and September is $-0.31 \times 10^{5} \mathrm{~kg} \mathrm{~s}^{-1},-0.69 \times 10^{5} \mathrm{~kg} \mathrm{~s}^{-1},-0.32 \times 10^{5} \mathrm{~kg} \mathrm{~s}^{-1}$, and $-0.15 \times 10^{5} \mathrm{~kg} \mathrm{~s}^{-1}$, respectively (Figure 9a2-d2), which evident that all the months of the season showed belowaverage moisture availability. As a result of less moisture flux, the country receives below normal rainfall during the SWM season. Furthermore, we notice that the largest negative NetMB is recorded in July concerning its long-term mean (Figure 9b2) because moisture outflux from the eastern and southern boundary is stronger than moisture influx from eastern and northern boundaries. The moisture influx from the eastern boundary showed a positive

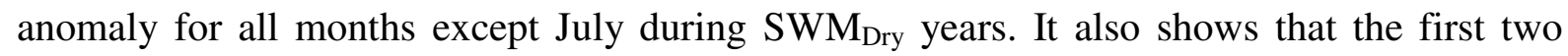
months of the season have a below-average moisture influx from the southern boundary, but the next two months of the season have above-average moisture flux during SWM $\mathrm{Mry}_{\text {years. }}$ During the $\mathrm{SWM}_{\text {Dry }}$ years, the eastern and northern boundaries act as outflux boundaries where outfluxes are above average compared to their climatological mean except June. For instance, moisture outflux in September recorded the largest positive anomaly for both eastern $\left(1.17 \times 10^{5} \mathrm{~kg} \mathrm{~s}^{-1}\right)$ and northern $\left(0.53 \times 10^{5} \mathrm{~kg} \mathrm{~s}^{-1}\right)$ boundary compared to the rest of the months (Figure 9a2-d2).

\subsection{Vertical Distribution of Moisture in Contrast Monsoon Years}

According to Anderson et al. (2009), the role of low jet stream flow is critical in the moisture flux fluctuations and precipitation. For instance, Ordóñez et al. (2012) found that the Arabian Sea and the Indian Ocean, through the action of Somali Low-Level Jets, are the most 
important source during the summer monsoon season. In particular, Malik et al. (2015) observe the largest moisture flux convergence at $925 \mathrm{hPa}$ level in summer and at $850 \mathrm{hPa}$ level in winter over central southwest Asia. Considering these facts, we also investigate the vertical distribution of regional moisture fluxes via each lateral boundaries for SWM seasons (Figure 10), where the climatology of moisture fluxes (shaded; Top x-axis) and the anomalous moisture fluxes in contrast monsoon years for each boundary are plotted (bottom $\mathrm{x}$-axis). We found that the eastward total moisture influxes via western boundaries in the lower troposphere from the surface to $700 \mathrm{hPa}$ was remarkably higher than the above $700 \mathrm{hPa}$ levels. We observed positive anomalous moisture fluxes via the western boundary from 1000 to $700 \mathrm{hPa}$ level (Figure 10a). After $700 \mathrm{hPa}$, negative anomalous moisture flux is reported to $450 \mathrm{hPa}$ level. In contrast, the anomalous moisture influx from the western boundary at all the pressure levels are almost close to the zero lines, which indicates that the difference between the long-term mean an influx from $\mathrm{SWM}_{\text {Dry }}$ is negligible (Figure 10a).

Compared to the western boundary, the southern boundary also acts as moisture input; however, the moisture influx via the southern boundary is smaller in magnitude (Figure 10c). According to the vertical structure of the southern boundary, moisture influx depicts large moisture transport from $1000 \mathrm{hPa}$ to $700 \mathrm{hPa}$; afterward, it is gradually decreasing from 700 In the eastern boundary, the maximum moisture outflux is observed from 950 and 850 $\mathrm{hPa}$ levels, while it is gradually decreasing up to $450 \mathrm{hPa}$ levels. In relatively wet monsoon years, the positive anomalous outflux is detected from the surface to $800 \mathrm{hPa}$ level; afterward, the outflux anomaly becomes negative up to $450 \mathrm{hPa}$ level. Interestingly we found that above-average moisture outflux from $1000 \mathrm{hPa}$ to $500 \mathrm{hPa}$ level during the $\mathrm{SWM}_{\text {Dry }}$ years; meanwhile, the difference with the long-term average is not remarkable from 500 to $300 \mathrm{hPa}$ levels (Figure 10b). 


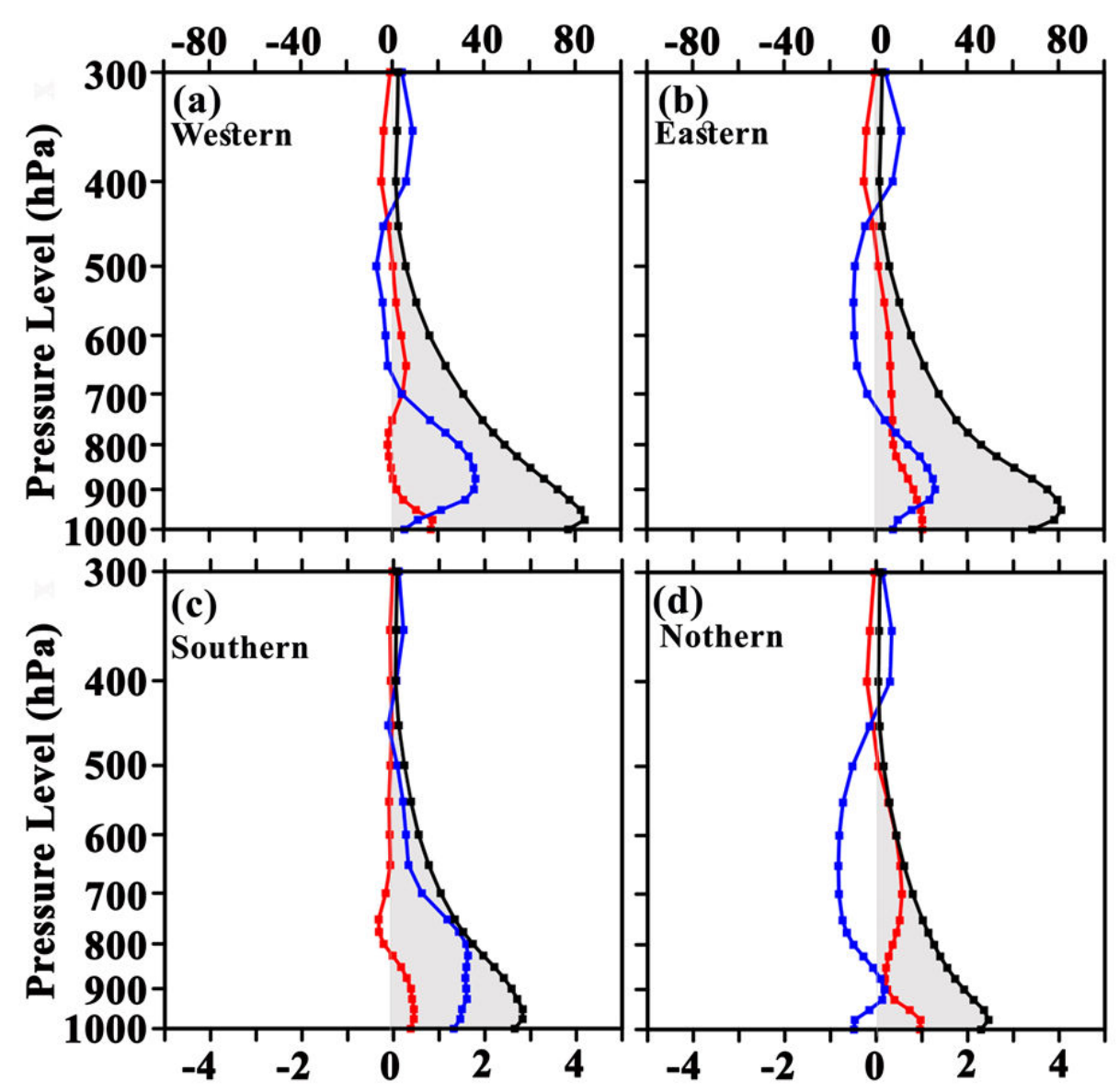

493

494 Figure 10 Vertical distribution of the total water vapor flux (unit: $10^{3} \mathrm{~m}^{2} \mathrm{~s}^{-1}$ ) via (a)

495

496

497

498

499

500

501

502

503

504

505

western boundary $\left(6^{\circ} \mathrm{N} \sim 10^{\circ} \mathrm{N}\right.$ at $\left.79.5^{\circ} \mathrm{E}\right)$ (b) eastern $\left(6^{\circ} \mathrm{N} \sim 10^{\circ} \mathrm{N}\right.$ at $\left.82^{\circ} \mathrm{E}\right)$, (c) southern $\left(79.5^{\circ} \mathrm{E} \sim 82^{\circ} \mathrm{E}\right.$ at $\left.6^{\circ} \mathrm{N}\right)$ and $(\mathrm{d})$ northern $\left(79.5^{\circ} \mathrm{E} \sim 82^{\circ} \mathrm{E}\right.$ at $\left.10^{\circ} \mathrm{N}\right)$ boundaries from the aspect of climate mean (black line, $\mathrm{x}$-axis at the top) and anomalous moisture flux ( $\mathrm{x}$-axis at the bottom) in relatively wet (blue line) and relatively dry SWM (red line) southwest monsoon (SWM) years.

As compared to moisture outflux from eastern boundaries, the moisture outflux via northern boundaries is smaller in magnitude (Figure 10d). The northern boundaries depict large moisture transport from $1000 \mathrm{hPa}$ to $850 \mathrm{hPa}$, gradually decreasing from 700-300 hPa levels. During $\mathrm{SWM}_{\mathrm{Wet}}$ years, negative anomalous outflux from the surface to the $450 \mathrm{hPa}$ level is dominant except for the $925-875 \mathrm{hPa}$ level. In contrast, the positive outflux anomaly is detected for the surface to $450 \mathrm{hPa}$ during the $\mathrm{SWM}_{\text {Dry }}$ years, which indicates that the 
moisture outflux from the northern boundary is higher in $\mathbf{S W M}_{\text {Dry }}$ years compared to the long-term mean of moisture outflux. This study revealed that the SWM rain in Sri Lanka also originated from the sea; mainly, a strong cross-equatorial low-level jet stream, with it is core close to the $850 \mathrm{hPa}$ level over the Indian Ocean.

\subsection{Moisture Fluxes Divergence in Contrast Monsoon Years}

The available moisture in an area mainly depends on the moisture flux divergence/ convergence than the moisture fluxes, which only measures the moisture passing through the study domain (Wei et al. 2015). On the other hand, moisture flux convergence is more important for the probability of intensifying rainfall. Therefore, we made an attempt to investigate anomalous vertically integrated Total Moisture Flux Divergence (TMFD), Zonal Moisture Flux Divergence (ZMFD), and Meridional Moisture Flux Divergence (MMFD) over the total averaged area of Sri Lanka for contrast SWM years. Meanwhile, the long-term mean TMFD, ZMFD, and MMFD, and an anomaly of divergence component for each month of the season are calculated (Figures 9a-c). Notably, we found a negative anomalous TMFD $\left(-1.78 \times 10^{-5} \mathrm{~kg} \mathrm{~m}^{-2} \mathrm{~s}^{-1}\right)$ in $\mathrm{SWM}_{\mathrm{Wet}}$ years compared to the long-term mean of TMFD ($\left.3.28 \times 10^{-5} \mathrm{~kg} \mathrm{~m}^{-2} \mathrm{~s}^{-1}\right)$. In contrast, positive anomalous TMFD $\left(1.44 \times 10^{-5} \mathrm{~kg} \mathrm{~m}^{-2} \mathrm{~s}^{-1}\right)$ is dominant for SWM Dry years (Figure 11a).

According to the monthly analysis, the long-term mean of TMFD in June, July, August, and September are $-3.31 \times 10^{-5},-3.55 \times 10^{-5},-2.99 \times 10^{-5}$, and $-3.2 \times 10^{-5} \mathrm{~kg} \mathrm{~m}^{-2} \mathrm{~s}^{-1}$, respectively. In $\mathrm{SWM}_{\mathrm{Wet}}$ years, we notice that all months in the SWM season show negative TMFD anomaly, while the lowest and highest TMFD anomaly is recorded in July $\left(-2.78 \times 10^{-}\right.$

$\left.{ }^{5} \mathrm{~kg} \mathrm{~m}^{-2} \mathrm{~s}^{-1}\right)$ and September $\left(-0.93 \times 10^{-5} \mathrm{~kg} \mathrm{~m}^{-2} \mathrm{~s}^{-1}\right)$, respectively (Figure 11a). In contrast, all months of the season recorded positive TMFD anomalies during the $\mathrm{SWM}_{\text {Dry }}$ years. For instance, the largest positive anomalous TMDF is recorded in June $\left(1.53 \times 10^{-5} \mathrm{~kg} \mathrm{~m}^{-2} \mathrm{~s}^{-1}\right)$. 
530 These findings suggest that negative TMFD may be more important for the heavier rainfall in 531 the regions, while other factors, such as local topography conditions, may have a strong 532 impact on localized rainfall during the SWM season. According to Wei et al. (2015), 533 enhanced moisture flux convergence (-divergence) increases with precipitation intensity. 534 Similarly, our result also suggests that above-average moisture convergence resulted in stong SWM rainfall. On the other hand, the below-average net moisture divergence caused rainfall subsidence during the SWM season, especially in $\mathrm{SWM}_{\text {Dry }}$ years. In parallel with our findings, Lin and Shelton (2020) found the frequent occurrence of drought events during the SWM season since 2000 due to the net moisture divergence anomalies over Sri Lanka.

To identify the behavior of the zonal and meridional components of the TMFD in contrast SWM years, we further analyze ZMFD and MMFD separately (Figures 11b-c).

541 Compared to the long-term average of the ZMFD in the SWM season $\left(-3.03 \times 10^{-5} \mathrm{~kg} \mathrm{~m}^{-2} \mathrm{~s}^{-1}\right)$, 542 the $\mathrm{SWM}_{\mathrm{Wet}}$ and $\mathrm{SWM}_{\text {Dry }}$ years recorded negative $\left(-2.75 \times 10^{-5} \mathrm{~kg} \mathrm{~m}^{-2} \mathrm{~s}^{-1}\right)$ and positive $\left(1.55 \times 10^{-5} \mathrm{~kg} \mathrm{~m}^{-2} \mathrm{~s}^{-1}\right)$ anomalies, respectively. The long-term mean of the ZMFD in June ($\left.5.86 \times 10^{-5} \mathrm{~kg} \mathrm{~m}^{-2} \mathrm{~s}^{-1}\right)$ and July $\left(-6.78 \times 10^{-5} \mathrm{~kg} \mathrm{~m}^{-2} \mathrm{~s}^{-1}\right)$ is negative, while the next two months of the season depict positive ZMFD (Figure 11b). The results further show all the months of the SWM season have negative (positive) ZMFD anomalies in the $\mathrm{SWM}_{\mathrm{Wet}}\left(\mathrm{SWM}_{\text {Dry }}\right)$ years. In $\mathrm{SWM}_{\mathrm{Wet}}$ years, the lowest negative ZMFD anomaly $\left(-3.24 \times 10^{-5} \mathrm{~kg} \mathrm{~m}^{-2} \mathrm{~s}^{-1}\right)$ is observed in August, while September recorded the highest divergence $\left(-2.03 \times 10^{-5} \mathrm{~kg} \mathrm{~m}^{-2} \mathrm{~s}^{-1}\right)$ compared to other months in the season (Figure 11b). 

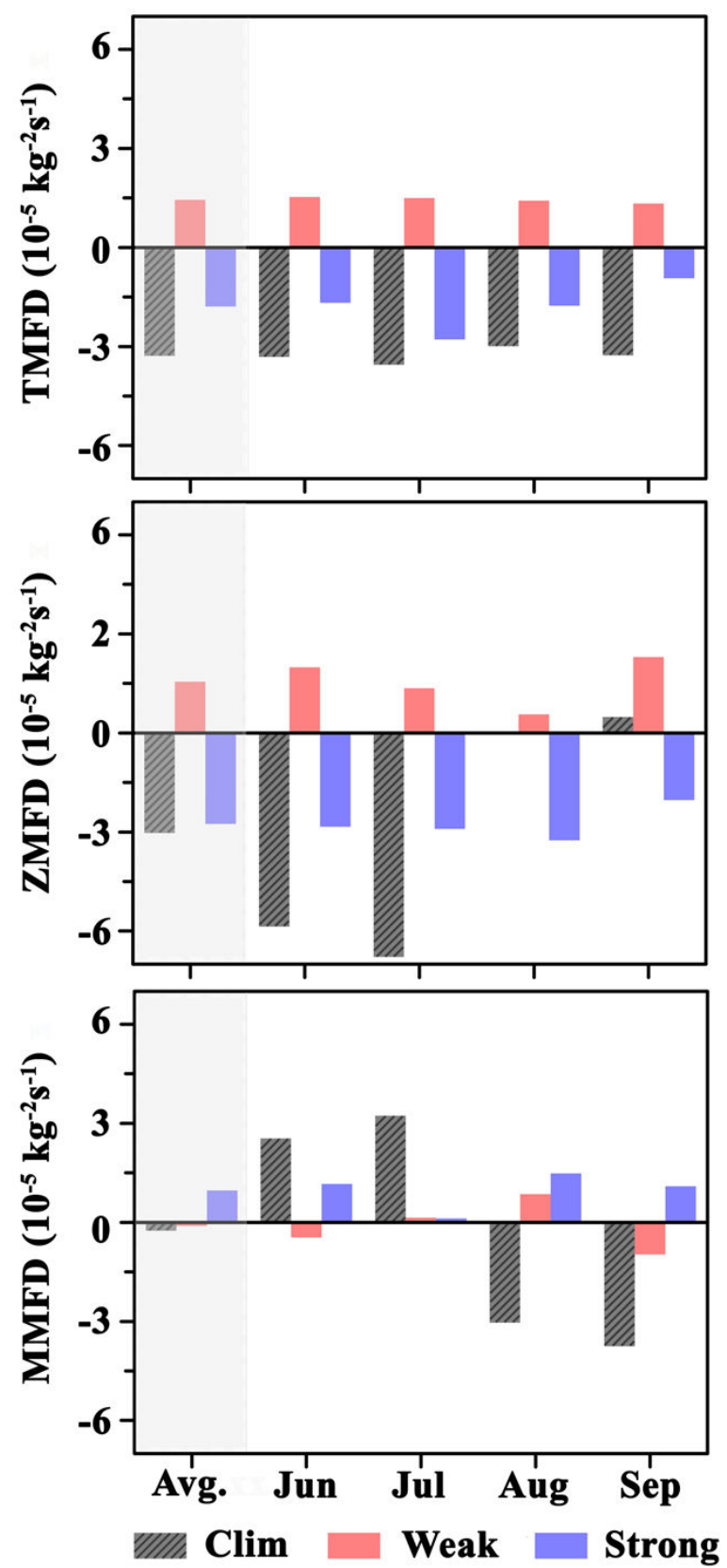

556 Figure 11 The area-averaged $\left(5.5^{\circ} \mathrm{N} \sim 10^{\circ} \mathrm{N}, 80^{\circ} \mathrm{E} \sim 82.5^{\circ} \mathrm{E}\right)$ seasonal and monthly

557 vertically integrated (a) Total Moisture Flux Divergence (TMFD), (b) Zonal Moisture Flux 558 Divergence (ZMFD) and Meridional Moisture Flux Divergence (MMFD) (units: $10^{-5} \mathrm{~kg} \mathrm{~m}^{-2}$ $559 \mathrm{~s}^{-1}$ ) for (a) a long-term average of southwest (SWM) season, and anomalies for for relatively 560 (b) wet $\left(\mathrm{SWM}_{\mathrm{Wet}}\right)$ and (c) dry SWM (SWM $\left.\mathrm{Sry}_{\text {Dry }}\right)$ years. The bars inside the shaded stip denote 561 the seasonal average climatology and anomalies in contrast SWM years. 
The long term average of MMFD for SWM season is $-0.65 \times 10^{-5}$, while positive

563

564

565

566

567

568

569

570

571

572

573

574

575

576

577

578

579

580

581

582

583

584

585

586

$\left(0.96 \times 10^{-5} \mathrm{~kg} \mathrm{~m}^{-2} \mathrm{~s}^{-1}\right)$ and negative $\left(-0.10 \times 10^{-5} \mathrm{~kg} \mathrm{~m}^{-2} \mathrm{~s}^{-1}\right)$ anomalous MMFD is observed in the $\mathrm{SWM}_{\text {wet }}$ and $\mathrm{SWM}_{\text {Dry }}$ years, respectively. We found that the June $\left(2.54 \times 10^{-5} \mathrm{~kg} \mathrm{~m}^{-2} \mathrm{~s}^{-1}\right)$ and July $\left(3.2 \times 10^{-5} \mathrm{~kg} \mathrm{~m}^{-2} \mathrm{~s}^{-1}\right)$ showed strong MMFD, which become negative in August ($\left.3.04 \times 10^{-5} \mathrm{~kg} \mathrm{~m}^{-2} \mathrm{~s}^{-1}\right)$ and September $\left(-3.74 \times 10^{-5} \mathrm{~kg} \mathrm{~m}^{-2} \mathrm{~s}^{-1}\right)$ as shown in Figure 11c. In $\mathrm{SWM}_{\mathrm{Wet}}$ years, all the months recorded positive divergence anomaly, where the largest positive anomaly $\left(1.48 \times 10^{-5} \mathrm{~kg} \mathrm{~m}^{-2} \mathrm{~s}^{-1}\right)$ is recorded for August. During the $\mathrm{SWM}_{\text {Dry }}$ years, June $\left(-0.45 \times 10^{-5} \mathrm{~kg} \mathrm{~m}^{-2} \mathrm{~s}^{-1}\right)$ and September $\left(-0.96 \times 10^{-5} \mathrm{~kg} \mathrm{~m}^{-2} \mathrm{~s}^{-1}\right)$ show a negative MMFD anomaly, while July $\left(0.14 \times 10^{-5} \mathrm{~kg} \mathrm{~m}^{-2} \mathrm{~s}^{-1}\right)$ and August $\left(0.85 \times 10^{-5} \mathrm{~kg} \mathrm{~m}^{-2} \mathrm{~s}^{-1}\right)$ report positive MMFD (Figure 11c). The above results indicate inhomogeneity in the monthly TMFD, ZMFD, and MMFD during the contrast SWM years, which characterizes the seasonal average of them. Based on the long-term climatology, negative ZMFD components dominant in the first two months of the SWM season, while the MMFD becomes negative in August and September. Finally, we identified that the negative (positive) TMFD anomalies over Sri Lanka could ascribe the above-average (below-average) rainfall in contrast SWM years.

\section{$4 \quad$ Discussion and Conclusion}

It is noticed that around $60 \%$ of the terrestrial precipitation directly originates as a result of moisture transported from the ocean (Gimeno et al. 2012) while excessive transports are usually primary sources for extreme weather and flood events (Galarneau et al. 2010), as well as interrupted transports, can lead to droughts and subsequent socioeconomic stresses. Therefore a clear understanding of the mechanisms that force observed changes to the hydrological cycle over Sri Lanka is crucial for water management and mitigate the metrological induce disasters. Hence, the present study has been focused on finding out a relationship between the variability of the oceanic moisture source and monsoon rainfall (SWM) variability during relatively wet and dry monsoon years over Sri Lanka. 

southern hemisphere is one of the most important sources of moisture for Sri Lanka during the relatively wet monsoon SWM years. Furthermore, we noticed that the deficiency of westerly moisture flux from the Arabian Sea results in below-average SWM rainfall over the country. This study revealed that the Sri Lankan summer monsoon rain is also originated from the sea; in particular, a strong cross-equatorial low-level jet stream, with it is core close to the $850 \mathrm{hPa}$ level over the Indian Ocean.

The vertically integrated moisture flux computation showed that the net positive divergence over the western Indian Ocean and negative moisture flux divergence over Sri Lanka, particularly, more negative VIMFD are concentrated to the west/southwest parts of the country during the $\mathrm{SWM}_{\mathrm{wet}}$, which can ascribe why this region receives havier rainfall during the SWM season. These positive moisture divergence developments were enhanced by the strong westerly winds over the West Indian Ocean while abundant moisture was located over Sri Lanka, which contributes to enhancing convection as well as cloud formation, thunderstorms, and rainfall during the $\mathrm{SWM}_{\mathrm{Wet}}$ years. In contrast, the whole country showed positive VIMFD during the relatively dry SWM years, which causes below-average SWM rainfall over the country. This moisture transport analysis assists in explaining the occurrence of extreme rainfall events in the SWM season in Sri Lanka; because many extreme rainfall events originate with high moisture and an atmospheric disturbance. Interestingly, we found below-average rainfall events after 2000 (6 events out of 9), which is resulted from the observed weakening of the South Asian monsoon, which leads to lesser moisture transport from the northwest Indian Ocean to Sri Lanka, with net moisture divergence anomalies (Lin and Shelton 2020).

Previous studies (Pandey et al. 2019; Varikoden and Preethi 2013) suggest that sea surface temperature also influences to enhancement and subsidence of SWM rainfall over 
612 India. For instance, above-average (below-average) SWM rainfall occurred during the La 613 Nina (El Nina) years over India. We also believe that SST over the Indian ocean and Pacific 614 Ocene modulate relatively wet and dry SWM years. In future studies, we will investigate how 615 SST changes and local evaporation affect the occurrence of above and below average SWM 616 event in Sri Lanka

\section{Author Contributions}

SS research conceptualization, methodology, formal analysis, data curation, writing original draft preparation, writing - review, and editing. All authors equally collaborated in the research presented in this publication by making the following contributions.

\section{$621 \quad$ Funding}

622 This study was jointly supported by the CAS Strategic Priority Research Program (Grant No. 623 XDA20060501), National Natural Science Foundation of China (41661144032), CAS The 624 Belt, and Road Initiative Program (134111KYSB20160010), and China-Sri Lanka joint 625 Center for Education and Research (CSL-CER).

626 Acknowledgments

627 We are thankful to the Meteorological Department, Sri Lanka, for providing weather data. SS acknowledged the CAS-TWAS President's Fellowship Program for International Ph.D. student and Industrial Technology Institute-Sri Lanka for their supports.

Conflicts of Interest: The author reported no potential conflict of interest.

\section{Availability of data and material}

632 The datasets generated during and/or analysed during the current study are available from the corresponding author on reasonable request.

\section{Code availability}

The codes used during the current study are not available. 
637 Ethics approval

638 Disclosure of potential conflicts of interest

639 Consent to participate

640 Not applicable

641 Consent for publication

642 Not applicable

643

644

\section{References}

645

646

647

648

649

650

651

652

653

654

655

656

657

658

659

660

661

662

663

664

665

Allan RP, Soden BJ (2007) Large discrepancy between observed and simulated precipitation trends in the ascending and descending branches of the tropical circulation Geophysical Research Letters 34:L18705 doi:https://doi.org/10.1029/2007GL031460

Anderson B, Ruane A, Roads J, Kanamitsu M (2009) Estimating the Influence of Evaporation and Moisture-Flux Convergence upon Seasonal Precipitation Rates. Part II: An Analysis for North America Based upon the NCEP-DOE Reanalysis II Model Journal of Hydrometeorology 10:893-911 doi:https://doi.org/10.1175/2009JHM1063.1

Dar SS, Ghosh P (2017) Estimates of land and sea moisture contributions to the monsoonal rain over Kolkata, deduced based on isotopic analysis of rainwater Earth Syst Dynam 8:313-321 doi:https://doi.org/10.5194/esd-8-313-2017

Dee DP et al. (2011) The ERA-Interim reanalysis: configuration and performance of the data assimilation system Quarterly Journal of the Royal Meteorological Society 137:553597 doi:https://doi.org/10.1002/qj.828

Galarneau TJ, Bosart LF, Schumacher RS (2010) Predecessor Rain Events ahead of Tropical Cyclones Monthly Weather Review 138:3272-3297 doi:https://doi.org/10.1175/2010mwr3243.1

Gao Q, Sun Y (2016) Changes in water vapor transport during the Meiyu season after 2000 and their relationship with the Indian ocean SST and Pacific-Japan pattern Dynamics of Atmospheres and Oceans 76:141-153

doi:http://dx.doi.org/10.1016/j.dynatmoce.2016.10.006 
Gimeno L et al. (2016) Major Mechanisms of Atmospheric Moisture Transport and their Role in Extreme Precipitation Events Annual Review of Environment and Resources 3:125 doi:https://doi.org/10.1146/annurev-environ-110615-085558

Gimeno L et al. (2012) Oceanic and terrestrial sources of continental precipitation Reviews of Geophysics 50:RG4003 doi:https://doi.org/10.1029/2012RG000389

Held IM, Soden BJ (2006) Robust Responses of the Hydrological Cycle to Global Warming Journal of Climate 19:5686-5699 doi:https://doi.org/10.1175/jcli3990.1

Joseph P, Simon A (2005) Weakening trend of the southwest monsoon current through peninsular India from 1950 to the present CURRENT SCIENCE 89:687-694

Joseph PV, Sijikumar S (2004) Intraseasonal Variability of the Low-Level Jet Stream of the Asian Summer Monsoon Journal of Climate 17:1449-1458 doi:https://doi.org/10.1175/1520-0442(2004)017<1449:IVOTLJ>2.0.CO;2

Kathayat $\mathrm{G}$ et al. (2016) Indian monsoon variability on millennial-orbital timescales Scientific Reports 6:24374 doi:https://doi.org/10.1038/srep24374

Konwar M, Parekh A, Goswami BN (2012) Dynamics of east-west asymmetry of Indian summer monsoon rainfall trends in recent decades Geophysical Research Letters 39:L10708 doi:https://doi.org/10.1029/2012GL052018

Levine RC, Turner AG (2012) Dependence of Indian monsoon rainfall on moisture fluxes across the Arabian Sea and the impact of coupled model sea surface temperature biases Climate Dynamics 38:2167-2190 doi:https://doi.org/10.1007/s00382-011$\underline{1096-\mathrm{Z}}$

Limin S, Oue H, Takase K (2015) Estimation of Areal Average Rainfall in the Mountainous Kamo River Watershed, Japan Journal of Agricultural Meteorology 71:90-97 doi:https://doi.org/10.2480/agrmet.D-14-00055

Lin Z, Shelton S (2020) Interdecadal Change of Drought Characteristics in Mahaweli River Basin of Sri Lanka and the Associated Atmospheric Circulation Difference Front Earth Sci 8:306-324 doi:https://doi.org/10.3389/feart.2020.00306

Liu B, Tan X, Gan TY, Chen X, Lin K, Lu M, Liu Z (2020) Global atmospheric moisture transport associated with precipitation extremes: Mechanisms and climate change impacts WIREs Water 7:e1412 doi:https://doi.org/10.1002/wat2.1412

Malik KM, Taylor PA, Szeto K (2015) Characteristics of moisture flux convergence in Central Southwest Asia Theoretical and Applied Climatology 120:643-659 doi:https://doi.org/10.1007/s00704-014-1192-1 
Malmgren BA, Hulugalla R, Hayashi Y, Mikami T (2003) Precipitation trends in Sri Lanka since the 1870s and relationships to El Niño--southern oscillation International Journal of Climatology 23:1235-1252 doi:https://doi.org/10.1002/joc.921

Marambe B et al. (2015) Climate, Climate Risk, and Food Security in Sri Lanka: Need for Strengthening Adaptation Strategies. doi:https://doi.org/10.1007/978-3-642-38670$\underline{1 \_120}$

Neiman PJ, Ralph FM, Moore BJ, Hughes M, Mahoney KM, Cordeira JM, Dettinger MD (2013) The Landfall and Inland Penetration of a Flood-Producing Atmospheric River in Arizona. Part I: Observed Synoptic-Scale, Orographic, and Hydrometeorological Characteristics Journal of Hydrometeorology 14:460-484 doi:https://doi.org/10.1175/jhm-d-12-0101.1

O’Gorman PA (2015) Precipitation Extremes Under Climate Change Current Climate Change Reports 1:49-59 doi:https://doi.org/10.1007/s40641-015-0009-3

Ordóñez P, Ribera P, Gallego D, Peña-Ortiz C (2012) Major moisture sources for Western and Southern India and their role on synoptic-scale rainfall events Hydrological Processes 26:3886-3895 doi:https://doi.org/10.1002/hyp.8455

Pandey V, Misra AK, Yadav SB (2019) Impact of El-Nino and La-Nina on Indian Climate and Crop Production. In: Sheraz Mahdi S (ed) Climate Change and Agriculture in India: Impact and Adaptation. Springer International Publishing, Cham, pp 11-20. doi:10.1007/978-3-319-90086-5_2

Pathak A, Ghosh S, Kumar P, Murtugudde R (2017) Role of Oceanic and Terrestrial Atmospheric Moisture Sources in Intraseasonal Variability of Indian Summer Monsoon Rainfall Scientific Reports 7:12729 doi:https://doi.org/10.1038/s41598-017$\underline{13115-7}$

Rajeevan M, Bhate J, Jaswal AK (2008) Analysis of variability and trends of extreme rainfall events over India using 104 years of gridded daily rainfall data Geophysical Research Letters 35 doi: https://doi.org/10.1029/2008gl035143

Ranatunge E, Malmgren BA, Hayashi Y, Mikami T, Morishima W, Yokozawa M, Nishimori M (2003) Changes in the Southwest Monsoon mean daily rainfall intensity in Sri Lanka: relationship to the El Nino-Southern Oscillation Palaeogeogr Palaeocl 197:114 doi:https://doi.org/10.1016/S0031-0182(03)00383-3

Ratna SB, A.Cherchi, Joseph PV, Behera S, Abish B, Masina S (2014) Moisture trend over the Arabian Sea and its influence on the indian summer monsoon precipitation. vol 225. Centro Euro-Mediterraneo per i Cambiamenti Climatici, Lecce, Italy 
Ratna SB, Cherchi A, Joseph PV, Behera SK, Abish B, Masina S (2016) Moisture variability over the Indo-Pacific region and its influence on the Indian summer monsoon rainfall Climate Dynamics 46:949-965 doi:https://doi.org/10.1007/s00382-015-2624-z

Rayner D, Chen D (2010) Extreme rainfall events in southern Sweden: where does the moisture come from? AU - Gustafsson, Malin Tellus A: Dynamic Meteorology and Oceanography 62:605-616 doi:https://doi.org/10.1111/j.1600-0870.2010.00456.x

Roxy MK et al. (2017) A threefold rise in widespread extreme rain events over central India Nature communications 8:708-708 doi:https://doi.org/10.1038/s41467-017-00744-9

Rubasinghe R, Gunatilake SK, Chandrajith R (2015) Geochemical characteristics of groundwater in different climatic zones of Sri Lanka Environmental Earth Sciences 74:3067-3076 doi:https://doi.org/10.1007/s12665-015-4339-1

Schneider U, Becker A, Finger P, Meyer-Christoffer A, Rudolf B, Ziese M (2011) GPCC full data reanalysis version 6.0 at $0.5^{\circ}$ : Monthly land-surface precipitation from raingauges built on GTS-based and historic data Deutscher Wetterdienst doi:https://doi.org/10.5676/DWD_GPCC/FD_M_V6_050

Shashikanth K, Salvi K, Ghosh S, Rajendran K (2014) Do CMIP5 simulations of Indian summer monsoon rainfall differ from those of CMIP3? Atmospheric Science Letters 15:79-85 doi:https://doi.org/10.1002/asl2.466

Shelton S, Lin Z (2019) Streamflow variability over the Period of 1990-2014 in Mahaweli River basin, Sri Lanka and Its Possible Mechanisms Water 11:2485-2506 doi: https://doi.org/10.3390/w11122485

Trenberth KE (1999) Conceptual Framework for Changes of Extremes of the Hydrological Cycle With Climate Change. In: Karl TR, Nicholls N, Ghazi A (eds) Weather and Climate Extremes: Changes, Variations and a Perspective from the Insurance Industry. Springer Netherlands, Dordrecht, pp 327-339. doi:https://doi.org/10.1007/978-94-015-9265-9_18

Trenberth KE, Dai A, Rasmussen RM, Parsons DB (2003) The Changing Character of Precipitation Bulletin of the American Meteorological Society 84:1205-1217 doi:https://doi.org/10.1175/bams-84-9-1205

Trenberth KE, Guillemot CJ (1998) Evaluation of the atmospheric moisture and hydrological cycle in the NCEP/NCAR reanalyses Climate Dynamics 14:213-231 doi:https://doi.org/10.1007/s003820050219

Turner AG, Annamalai H (2012) Climate change and the South Asian summer monsoon Nature Clim Change 2:587-595 doi:https://doi.org/10.1038/nclimate1495 
Ullah K, Gao S (2012) Moisture transport over the Arabian Sea associated with summer rainfall over Pakistan in 1994 and 2002 Advances in Atmospheric Sciences 29:501508 doi:http://dx.doi.org/10.1007/s00376-011-0200-y

Varikoden H, Preethi B (2013) Wet and dry years of Indian summer monsoon and its relation with Indo-Pacific sea surface temperatures International Journal of Climatology 33:1761-1771 doi:10.1002/joc.3547

Wang Z et al. (2017) Does drought in China show a significant decreasing trend from 1961 to 2009? Science of The Total Environment 579:314-324 doi:https://doi.org/10.1016/j.scitotenv.2016.11.098

Wasko C, Lu WT, Mehrotra R (2018) Relationship of extreme precipitation, dry-bulb temperature, and dew point temperature across Australia Environmental Research Letters 13:074031 doi:https://doi.org/10.1088/1748-9326/aad135

Wei J, Su H, Yang Z-L (2015) Impact of moisture flux convergence and soil moisture on precipitation: A case study for the southern United States with implications for the globe Climate Dynamics 46 doi:https://doi.org/10.1007/s00382-015-2593-2

Xavier A, Kottayil A, Mohanakumar K, Xavier PK (2018) The role of monsoon low-level jet in modulating heavy rainfall events International Journal of Climatology 38:e569e576 doi:https://doi.org/10.1002/joc.5390 
